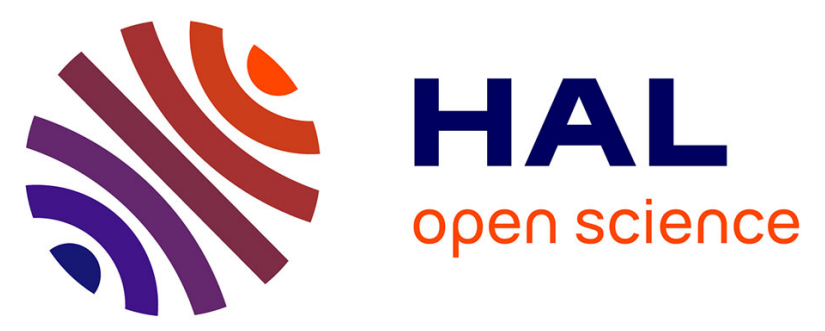

\title{
Millennial-scale deglaciation across the European Alps at the transition between the Younger Dryas and the Early Holocene - evidence from a new cosmogenic nuclide chronology
}

Marie Protin, Irene Schimmelpfennig, Jean-louis Mugnier, Jean-françois

Buoncristiani, Melaine Le Roy, Benjamin Pohl, Luc Moreau

\section{To cite this version:}

Marie Protin, Irene Schimmelpfennig, Jean-louis Mugnier, Jean-françois Buoncristiani, Melaine Le Roy, et al.. Millennial-scale deglaciation across the European Alps at the transition between the Younger Dryas and the Early Holocene - evidence from a new cosmogenic nuclide chronology. Boreas, 2021, 50 (3), pp.671-685. 10.1111/bor.12519 . hal-03290256v2

\section{HAL Id: hal-03290256 \\ https://hal.science/hal-03290256v2}

Submitted on 13 Jan 2022

HAL is a multi-disciplinary open access archive for the deposit and dissemination of scientific research documents, whether they are published or not. The documents may come from teaching and research institutions in France or abroad, or from public or private research centers.
L'archive ouverte pluridisciplinaire HAL, est destinée au dépôt et à la diffusion de documents scientifiques de niveau recherche, publiés ou non, émanant des établissements d'enseignement et de recherche français ou étrangers, des laboratoires publics ou privés. 
Millennial-scale deglaciation across the European Alps at the

2 transition between the Younger Dryas and the Early Holocene -

3 evidence from a new cosmogenic nuclide chronology

MARIE PROTIN, IRENE SCHIMMELPFENNIG, JEAN-LOUIS MUGNIER, JEAN-

FRANCCOIS BUONCRISTIANI, MELAINE LE ROY, BENJAMIN POHL, LUC MOREAU AND ASTER TEAM

Protin, M., Schimmelpfennig, I., Mugnier, J.-L., Buoncristiani, J.-F., Le Roy, M., Pohl, B., Moreau, L. \& ASTER Team: Millennial-scale deglaciation across the European Alps at the transition between the Younger Dryas and the Early Holocene - evidence from a new cosmogenic nuclide chronology. Boreas....

Reconstructing the spatial and temporal response of mountain glaciers to rapid climate change in the past provides access to the effects of current climate change. Yet, the spatial and temporal variability of past glacier fluctuations is not fully understood. In this study, we focus on the timing of glacier fluctuations in the European Alps during the Younger Dryas/Early Holocene (YD/EH) transition. In an effort to elucidate whether glacier fluctuations were synchronous during this period, we present a new chronology of the Alpine Talèfre glacier, based on 14 new ${ }^{10} \mathrm{Be}$ ages of moraines and roches moutonnées. The retreat of Talèfre glacier was initiated during the mid-YD ( 12.4 ka), then it experienced a gradual retreat punctuated by at least 3 oscillations until $\sim 11$ ka before shrinking substantially within its Little Ice Age limits (13th 19th century). Comparison of our findings with published glacier chronologies in the Alpine region highlights broadly synchronous behaviour of glaciers across the Alps between 12 and $10 \mathrm{ka}$. The coeval glacier fluctuations at a regional scale suggest that common regional climate conditions had a major impact on Alpine glacier variations during the YD/EH transition. The similarity of glacier behaviour and independent temperature records in both the Alpine region and the northern high latitudes suggests a teleconnection between these regions, but differences 
in the amplitude of the mean annual temperature signals relative to summer temperature indicate pronounced changes in seasonality between the YD and the EH.

Marie Protin (marie.protin@univ-lorraine.fr), Aix-Marseille Université, CNRS, IRD, INRA, Coll France, CEREGE, Aix en Provence, France and Université de Lorraine, CNRS, CRPG, F-54000 Nancy, France; Irene Schimmelpfennig and ASTER Team (Georges Aumaître, Didier Bourlès, Karim Keddadouche), Aix-Marseille Université, CNRS, IRD, INRA, Coll France, CEREGE, Aix en Provence, France; Jean-Louis Mugnier, Université Grenoble Alpes, Université Savoie Mont Blanc, CNRS, ISTerre, 73000 Chambéry, France; Jean-François Buoncristiani and Benjamin Pohl, Biogéosciences, UMR 6282 CNRS, Université Bourgogne Franche-Comté, 6 Boulevard Gabriel, 21000 Dijon, France; Melaine Le Roy, University of Geneva, Institute for Environmental Sciences, Climate Change Impacts and Risks in the Anthropocene (C-CIA), CH-1205 Geneva, Switzerland and Université Grenoble Alpes, Université Savoie Mont Blanc, CNRS, EDYTEM, 73000 Chambéry, France; Luc Moreau, Université Grenoble Alpes, Université Savoie Mont Blanc, CNRS, EDYTEM, 73000 Chambéry, France; received 23rd November 2020, accepted 11th February 2021.

Mountain glaciers are recognized as sensitive recorders of climate variability, and their fluctuations mainly depend on variations of both temperature during the melt season and snow precipitation (Oerlemans 2005; Roe et al. 2017). In the case of Alpine glaciers, their recent evolution is controlled by large-scale climate variations moderated by local specific factors (Rabatel et al. 2013; Vincent et al. 2017). In the light of current climate evolution and rapid retreat of glaciers worldwide, it is important to improve our understanding of the sensitivity of glaciers to rapid climate changes in the past, such as those during the Younger Dryas/Early 
54 climate variations versus local climate and site-specific factors has to be better assessed by constraining past glacial chronologies.

Moraines and roches moutonnées represent clear geomorphic markers of past glacier extents. Studying and dating them is a valuable approach for constraining former glacier behaviour, establishing glacier chronologies and investigating the related climate changes. Due to the lack of direct dating methods, the traditional chronology of glacier advances ("stadials") in the Alps during the period of Lateglacial and EH deglaciation is mainly based on comparative studies of moraine stratigraphies and morphologies and on the variation of the equilibrium line altitude (ELA) (e.g. Maisch 1981). Temporal correlations of these stadials with palaeoclimatic periods were broadly confirmed by the pioneering cosmogenic nuclide studies at a few Alpine sites (see reviews in Ivy-Ochs et al. 2006 and Ivy-Ochs 2015). For instance, the Egesen stadial moraines are assigned to the Younger Dryas (from 12.9 to $11.7 \mathrm{ka}$; Rasmussen et al. 2006), and are associated with an ELA depression of 250-350 m relative to the Little Ice Age (LIA) (IvyOchs 2015). The Kartell stadial moraines are assigned to the Preboreal cold period (11.4- 11.3 ka; Kobashi et al. 2008) with an ELA depression of 120 m (Ivy-Ochs 2015). However, recent studies showed that correlating moraines from different Alpine valleys solely based on the above-mentioned comparative criteria is unreliable, highlighting the need for direct moraine dating with cosmogenic nuclides when comparing moraines from various sites (e.g. Reitner et al. 2016; Boxleitner et al. 2019).

Over the past few years, parameters for the calculations of cosmic ray exposure ages were refined (e.g. Balco et al. 2008, 2009; Young et al. 2013; Borchers et al. 2016; Balco 2017; Martin et al. 2017) and an increasing number of cosmogenic nuclide dating studies from the Alps have been published, providing evidence of multiple glacier fluctuations during the Lateglacial and the EH (e.g. Schindelwig et al. 2012; Moran et al. 2016a, b; Baroni et al. 2017). Attempts of identifying temporal or spatial trends in Alpine glacier behaviour during the 
79 Lateglacial and EH have been made in earlier studies (Schimmelpfennig et al. 2014; Chenet et

al. 2016; Braumann et al. 2020). Although age uncertainties are generally too large to infer clear trends, an abrupt glacier recession is not documented in the Alps at the very sharp transition between YD and Holocene that is observed in Greenland ice cores with $\mathrm{a} \sim 10{ }^{\circ} \mathrm{C}$ warming in less than one hundred years.

Rather, previous studies suggested that EH glacier stillstands or advances in the Alps could be a response to abrupt cold spells observed in Greenland ice cores (e.g. Ivy-Ochs et al., 2009; Schindelwig et al. 2012; Schimmelpfennig et al. 2012, 2014), such as the Preboreal Oscillation or a cold event notable at $\sim 10.9 \mathrm{ka}$ (Rasmussen et al. 2006; Vinther et al. 2006).

In the Western Alps, glacier chronologies from Lateglacial and $\mathrm{EH}$ have for a long time been very scarce, but recent robust records and additional data from the French Alps will now provide the opportunity to use the Alpine data set as a whole for a regional analysis (e.g. Cossart et al. 2012; Chenet et al. 2016; Hofmann 2018; Protin et al. 2019; Schimmelpfennig et al. 2019). The chronological investigation of these moraine chronologies could lead to a better understanding of the large-scale palaeoclimatic conditions during a period for which proxy and model data still show diverging temperature trends in both mid- and high latitudes: coupled ocean-atmosphere climate models (e.g. Buizert et al. 2014) failed to reproduce the abrupt warming at the end of the YD found in North Atlantic and Greenland ice cores (e.g. Rasmussen et al. 2006; Shakun et al. 2015), whereas continental temperature reconstructions based on biological proxies either fit with this drastic warming (chironomid records in Heiri et al. 2015) or indicate a much more gradual warming (e.g. pollen records in Marsicek et al. 2018 and glacier chronologies in Rainsley et al. 2018, and Young et al. 2020).

In this study, we provide a new glacier chronology in the French Alps by analyzing the Talèfre glacier patterns during the deglaciation of the "Jardin de Talèfre", one of the highest moraine sites in the Alps (close to $3000 \mathrm{~m}$ a.s.1.), where a set of moraines is deposited above 
104 roches moutonées. We present new in-situ cosmogenic beryllium-10 $\left({ }^{10} \mathrm{Be}\right)$ ages of moraines

105 and roches moutonnées for this area and compare these new data with published ${ }^{10} \mathrm{Be}$ glacial 106 chronologies from elsewhere in the European Alps, selected for their quality (e.g. number of 107 samples, dispersion of the ages) and re-calculated using uniform methods. Building on this 108 regional compilation, we evaluate (i) the possibility of a regional synchroneity of glacier 109 fluctuations during the multi-millennia period of the end of the YD and the beginning of the 110 Holocene (hereafter YD/EH transition), (ii) the impact of large-scale climate variations on 111 glacier patterns versus site-specific factors, (iii) the underlying climatic drivers in a regional 112 scale and their potential link with the high-latitudes, and (iv) the climatic significance of the 113 small fluctuation range of glacier extent between the YD and EH in the light of the significant 114 and abrupt climate change recorded in independent proxy records.

116 Study site

118 Talèfre glacier $\left(45^{\circ} 54^{\prime} \mathrm{N}, 6^{\circ} 59^{\prime} \mathrm{E}\right)$ is a cirque glacier located in the French part of the Mont119 Blanc massif and was a major tributary of Mer de Glace glacier, the largest glacier in the Mont120 Blanc massif (Fig. 1). To the north is located the Argentière glacier, the second largest glacier 121 in the Mont-Blanc massif (Fig. 1). In 2008, Talèfre glacier covered an area of $\sim 8 \mathrm{~km}^{2}$ with a 122 maximum length of $4.5 \mathrm{~km}$ and altitude spanning 2473 to $3743 \mathrm{~m}$ a.s.1. (Gardent 2014). The 123 ELA of Talèfre glacier for the period 1984-2010 was estimated to $\sim 3000 \mathrm{~m}$ a.s.l. (Rabatel et al. 124 2013). Next to Argentière glacier, the mean annual temperature and precipitation for the time 125 period $1979-2002$ are estimated at $1.8^{\circ} \mathrm{C}$ and $1783 \mathrm{~mm}$ at $\sim 2000 \mathrm{~m}$ a.s.1. (Joly et al. 2018; D. 126 Joly pers. comm. 2018). The catchment of Talèfre glacier is bordered by granite rocks of late 127 Hercynian age ( 300 Ma; Bussy et al. 2000). 
During the YD, Talèfre glacier was connected to Mer de Glace, which at that time

129 occupied the Arve Valley with a front located westward of the left boundary of Fig. 1

130 (Prud'homme et al. 2020). During the last LIA advance in the 19th century, Talèfre glacier was

131 confluent with Leschaux glacier, which further downvalley joins Tacul glacier to form Mer de

132 Glace (Fig. 1). Since $\sim 1950$ the Talèfre and Leschaux glaciers have not been coalescing

133 (Gardent 2014).

134 A notable feature of Talèfre glacier is the presence of a triangle-shaped rock islet at its 135 center, named "Jardin de Talèfre" (i.e. Talèfre garden). This islet is bounded by moraines (Fig. 136 2), that span 2640 to $3040 \mathrm{~m}$ a.s.l. (Jordan 2010). Because of its remoteness, this area has not 137 been disturbed by human activity. According to the French État-Major maps (surveyed in 1820138 1866) and first available photographs made by August-Rosalie Bisson in 1862 the "Jardin de 139 Talèfre" was not ice-covered during the last LIA maximum (de Decker Heftler 2002).

141 Methodology

142 Moraine mapping

144 Several so-far undated moraine ridges preserved on the islet were studied and represented in 145 the geomorphological map of Fig. 3. The mapping was conducted through field work and 146 interpretation of aerial images from the year 2015 (French national institute of geographic and 147 forest information - IGN, $50 \mathrm{~cm}$ resolution).

149 Sample collection

151 Fourteen samples were collected in the "Jardin de Talèfre", 2 from smoothed bedrock surfaces 152 resulting from glacial erosion and 12 from moraine boulders (Fig. 3). Bedrock samples were 
153 taken from the surface of the rocky islet, and attention was paid to avoid the possibility of cover

154 by snow or vegetation and significant erosion by choosing sloping spots with glacial

155 morphologies (Fig. 2C). Both surfaces were covered by lichen. Moraine boulder samples were

156 taken from the top of the boulders, which were embedded in the crest or slope of the targeted

157 moraines (Fig. 2D). If we assume uninterrupted surface exposure, the bedrock exposure ages

158 indicate when the "Jardin de Talèfre" became ice-free for the last time, while the boulder

159 exposure ages represent the timing of the glacier culmination and moraine stabilization (for

160 detailed discussion see section "Oscillation of Talèfre glacier since the Younger Dryas").

161 Samples were collected using a chisel, a hammer and a cordless angle grinder, and topographic

162 shielding was evaluated in the field using a clinometer.

163

164 Laboratory procedures

165

166 All samples were processed at CEREGE (Aix-en-Provence, France). Samples were crushed and

167 sieved to collect the $250-500 \mu \mathrm{m}$ fraction. Quartz was first concentrated by magnetic separation

168 and then isolated by successive leaching in $\mathrm{a}_{2} \mathrm{SiF}_{6} / \mathrm{HCl}$ mixture or by froth flotation when the

169 mineralogy allowed it. The obtained quartz fraction was leached at least two times in a 5\% HF

$170-5 \% \mathrm{HNO}_{3}$ solution, followed by $24 \mathrm{~h}$ in ultra-sonic baths in a $1 \% \mathrm{HF}-1 \% \mathrm{HNO}_{3}$ solution in

171 order to remove any remaining feldspars and to clean the grains from atmospheric ${ }^{10} \mathrm{Be}$. Purified

172 quartz was completely dissolved in concentrated HF after addition of $\sim 0.1 \mathrm{~g}$ of an in-house ${ }^{9} \mathrm{Be}$

173 carrier solution ( $3025 \pm 9$ ppm; Merchel et al. 2008). Beryllium was extracted by successive

174 alkaline precipitations of $\mathrm{Be}(\mathrm{OH})_{2}$ alternated with separation on anion and cation columns.

175 Samples were then oxidized at $700{ }^{\circ} \mathrm{C}$ for one hour and the final $\mathrm{BeO}$ mixed with $\mathrm{Nb}$ powder

176 and loaded into nickel cathodes. Measurements of the ${ }^{10} \mathrm{Be} /{ }^{9} \mathrm{Be}$ ratios by accelerator mass

177 spectrometry (AMS) were conducted at the French national AMS facility ASTER (Arnold et 
178 al. 2010). Samples were calibrated against in-house standard STD- 11 with a ${ }^{10} \mathrm{Be} /{ }^{9} \mathrm{Be}$ ratio of

$179(1.191 \pm 0.013) \times 10^{-11}$ (Braucher et al. 2015) and a ${ }^{10} \mathrm{Be}$ half-life of $(1.387 \pm 0.0012) \times 10^{6}$ years

180 (Chmeleff et al. 2010; Korschinek et al. 2010). Analytical uncertainties combine ASTER

181 counting statistics and stability ( $\sim 5 \%$; Arnold et al. 2010$)$ and machine blank correction. The

182 number of atoms ${ }^{10} \mathrm{Be}$ in the samples calculated from the corresponding ${ }^{10} \mathrm{Be} /{ }^{9} \mathrm{Be}$ ratios was

183 then corrected from that of the chemical blanks, which had ${ }^{10} \mathrm{Be} /{ }^{9} \mathrm{Be}$ ratios of $(3.38 \pm 0.49) \times 10^{-15}$

184 and $(3.48 \pm 0.50) \times 10^{-15}$ (Table 1$)$.

185

186 Age calculations

187

188 Surface exposure ages of the here presented new data were computed with the CREp online 189 calculator (Martin et al. 2017) using the Lal-Stone time corrected scaling scheme Lm, the 190 ERA40 atmospheric reanalyses and the Atmospheric ${ }^{10}$ Be-based VDM for geomagnetic 191 database (see Martin et al. 2017 and references therein). We applied the production rate of $1924.10 \pm 0.10$ atoms ${ }^{10} \mathrm{Be} \mathrm{g}^{-1} \mathrm{a}^{-1}$ established by Claude et al. (2014) as it is the only regional ${ }^{10} \mathrm{Be}$ 193 production rate available for Alpine sites and it is identical to the global ${ }^{10} \mathrm{Be}$ production rate 194 resulting from the ICE-D database linked to CREp $\left(4.11 \pm 0.19\right.$ atoms $\left.{ }^{10} \mathrm{Be} \mathrm{g}^{-1} \mathrm{a}^{-1}\right)$. The two other 195 production rates often used for studies in the Alps, i.e. the northeast North America "NENA" 196 production rate (Balco et al. 2009) and the "Arctic" production rate (Young et al. 2013), which 197 is almost identical with the recent Scotland production rate (Putnam et al. 2019), would lead to 198 ages older by less than $2 \%$ and $1 \%$, respectively. For easy comparison, we present in Table 1 199 the exposure ages calculated with both the regional production rate and the "Arctic" production 200 rate. We did not apply a correction for snow shielding, as we do not have sufficient quantitative 201 data on snowfall during the Holocene, and all sampled surfaces are in wind-exposed locations. 202 We did not correct for potential erosion, as we were careful to sample surfaces with least 
203 possible erosion. Applying a correction for considerable snow cover assuming $50 \mathrm{~cm}$ of snow 204 for six months (Chenet et al. 2016) would lead to ages older by $6 \%$ to 8\%. Applying a correction 205 for erosion corresponding to an erosion rate of $1 \mathrm{~mm} \mathrm{ka}^{-1}$ (André 2002) would result in ages 206 older by less than $1 \%$.

For the regional comparison of glacier records, previously published data from 18 study 208 sites (see references in Fig. 6) were homogenized by re-calculating the individual and mean 209 ages using the same procedures as above (Table S1). Boulders identified as outliers in the 210 original studies were kept as outliers. Applying the $\chi^{2}$ test $(2 \sigma)$ by Ward \& Wilson (1978), 211 moraine age populations were tested for outliers, which were also discarded as indicated in 212 Table S1. Exceptions were made for the moraine M7a from the Rougnoux valley, M2 from 213 Falgin cirque and the lower moraine from Steingletscher, where all boulders (not identified as 214 outliers by authors) were kept for the mean age calculation even if they statistically mismatch, 215 as we do not have any argument for discarding a specific sample from the age population. At 216 the Rougnoux valley site, several moraine mean ages do not agree with the stratigraphic order 217 (M8-9, M7b, M4-5 and M6b) but these ages do not statistically differ; therefore, we choose to 218 include them all in the comparison. We eliminated from the comparison the moraine ages that 219 are based on only one sample and that have standard deviations $>10 \%$ to make the comparison 220 as accurate as possible. Once this selection made, only the sites with at least one moraine of 221 Holocene age $(<11.7 \mathrm{ka})$ were kept for the comparison in order to exclude sites with moraines 222 that exclusively correspond to earlier Lateglacial advances. Boxleitner et al. (2019) dated 34 223 moraine boulders of several glacier systems in Meiental (central Alps), but we deliberately did 224 not consider the study in our test, because each moraine was dated with only one boulder. 225 Applying a realistic snow cover correction to all sites would equally shift all moraine ages to 226 slightly older dates and would not affect the discussion. 
228 Results

229 Geomorphological description of the Talèfre site

230

231 Two massive lateral moraines, up to $50 \mathrm{~m}$ high and $1 \mathrm{~km}$ long, frame the islet of the "Jardin de 232 Talèfre" (purple moraines, including T4, in Fig. 2B and Fig. 3). In the eastern part of the islet, 233 three very smooth lateral moraine ridges (T1, T2 and T3) are visible in stratigraphically older

234 location relative to the massive moraine T4 on the eastern margin. They are less than $2 \mathrm{~m}$ high 235 and between 100 and $200 \mathrm{~m}$ long. The two outermost of these three moraine ridges (T1 and T2) 236 bear several large boulders suitable for ${ }^{10} \mathrm{Be}$ dating, while the ridge $\mathrm{T} 3$ does not. These three 237 ridges (T1 to T3) are represented in dark blue in Fig. 2B and Fig. 3. Moraine mapping shows 238 that they are leaning northward against a $20 \mathrm{~m}$ high rock slope at an altitude of $\sim 2850 \mathrm{~m}$ a.s.l.; 239 to the south, they are crosscut by the T4 moraine. Between the western massive ridge and the 240 present glacier margin, a small ridge (T5) is visible (pink moraine in Fig. 3). It has no equivalent 241 on the eastern side and has been probably deposited during one of the short advances/stillstands 242 that occurred at Alpine sites during the general glacier retreat of the 20th century 243 (Schimmelpfennig et al. 2014; Braumann et al. 2020).

Moraine and bedrock exposure ages of Talèfre glacier

247 The two bedrock surfaces were sampled at the center of the northern part of the "Jardin de 248 Talèfre". Moraine boulder samples were taken from three ridges in the eastern part of the islet, 249 i.e. from the two stratigraphically outermost (oldest), smooth moraines T1 and T2, and from 250 the innermost (youngest), massive moraine T4. Surface exposure ages are shown in Fig. 3 and 251 detailed in Table 1. Probability plots of moraine boulder ages and arithmetic mean ages are 252 shown in Fig. 4. The consistency of individual ages within one moraine age populations were 
253 tested for outliers with the $\chi^{2}$ test $(2 \sigma)$ by Ward \& Wilson (1978), using the analytical 254 uncertainties of the ages. In the text and in figures, individual ages are given with the analytical 255 uncertainties, to allow for internal comparison, and arithmetic mean ages are given with their 256 standard deviations, while Table 1 shows both analytical uncertainties and total uncertainties 257 (including the ${ }^{10} \mathrm{Be}$ rate uncertainty). See figure and table captions for details.

258 All ages are in agreement with their stratigraphic order. The two bedrock samples, JDT259 16-1 and JDT-16-2, give indistinguishable exposure ages of $12.4 \pm 0.4$ and $12.3 \pm 0.3 \mathrm{ka}$, 260 respectively. The three boulder ages from the outermost moraine T1 range between $12.2 \pm 0.4$ 261 and $11.6 \pm 0.3 \mathrm{ka}$, with a mean age of $12.0 \pm 0.4 \mathrm{ka}$. Three boulder ages from moraine $\mathrm{T} 2$ are very 262 well clustered between $11.4 \pm 0.3$ and $11.1 \pm 0.3 \mathrm{ka}$ and give a mean age of $11.2 \pm 0.2 \mathrm{ka}$ after 263 discarding JDT-16-20 as an outlier (10.2 $\pm 0.3 \mathrm{ka})$. This boulder is less than $1 \mathrm{~m}$ high. It might 264 thus have been exhumed or covered for a while by a layer of sediment, leading to an 265 underestimation of its exposure age. On the innermost moraine, four boulders yield ages of $2660.18 \pm 0.02,0.22 \pm 0.03,0.26 \pm 0.02$ and $0.33 \pm 0.03 \mathrm{ka}$ and one boulder is dated at $2.12 \pm 0.07 \mathrm{ka}$.

267 According to this new set of exposure ages we propose a reconstruction of the past 268 extents of Talèfre glacier, corresponding to moraines T1 and T4 (Fig. 5). The mapping of the 269 exterior glacier margins relies solely on remnants of undated moraines, assumed variations in 270 relation to catchment slopes, and 19th century maps from French État-Major.

\section{Exposure ages of other Alpine chronologies}

273

274 The previously published 18 Alpine glacier chronologies that are considered here are 275 characterized by sets of lateral and/or latero-frontal moraines originally dated between $\sim 13.5$ 276 and $\sim 9.5 \mathrm{ka}$. Of these 18 sites, 11 meet the quality criteria presented in the section 277 "Methodology" and yield recalculated ${ }^{10} \mathrm{Be}$ exposure ages between 14.5 and $9.8 \mathrm{ka}$. The 
278 moraine ages of the other sites are either older (Val Viola, Gesso della Barra valley, Romanche 279 valley, Great Aletsch glacier, Ferwall site) or show large standard deviations (Clarée valley). 280 Probability curves for all retained moraine mean ages in each site are plotted in Fig. 6 in 281 comparison with the Talèfre glacier moraine ages.

282

283 Discussion

284 Oscillations of Talèfre glacier since the Younger Dryas

285

286 According to the exposure ages of the two bedrock samples, the "Jardin de Talèfre" deglaciation 287 started at $\sim 12.4 \mathrm{ka}$, i.e. during the YD period, if a continuous exposure scenario is assumed. 288 Alternatively, the duration of $\sim 12.4$ ka could be composed of several exposure periods, e.g. a 289 few hundred years of ice-free conditions during the warmer Bølling/Allerød ( 14.7 - $12.9 \mathrm{ka}$; 290 Lotter et al. 2000; Rasmussen et al. 2006) and subsequent burial by the re-advancing glacier at 291 the beginning of the YD. However, the only slightly younger mean age of moraine T1 (12.0 \pm 0.4 292 ka) implies that "Jardin de Talèfre" was deglaciated during the YD and the central rock islet 293 has remained ice-free since that time. The mean ages of moraines $\mathrm{T} 1$ and $\mathrm{T} 2$ are 294 stratigraphically consistent $(12.0 \pm 0.4$ and $11.2 \pm 0.2 \mathrm{ka})$ and coincide with the $\mathrm{YD} / \mathrm{EH}$ transition. 295 We propose that the $\mathrm{T} 3$ moraine was deposited during the $\mathrm{EH}$, as its morphology is very similar 296 to T1 and T2 moraines. This suggests that the glacier underwent at least three advances or 297 stillstands after the beginning of its retreat $\sim 12.4$ ka ago until the EH.

298 Four out of the five ages acquired from moraine T4 span from $0.18 \pm 0.02$ to $0.33 \pm 0.03$ $299 \mathrm{ka}$, with a mean age of $0.25 \pm 0.06 \mathrm{ka}$. These results indicate that the moraine was last overtopped 300 at the end of the LIA, when several closely-spaced advances occurred. One out of the five 301 samples of T4 is significantly older, $2.12 \pm 0.07 \mathrm{ka}$ (JDT-16-3). This older age can be either 302 explained by isotope inheritance from a previous exposure duration or by accretion phases of 
303 this massive moraine that pre-dated the deposition of the LIA boulders. Such advances prior to 304 the LIA have been reported for other glaciers in the French Alps: between $\sim 3.5$ and 0.7 ka at 305 Mer de Glace (Le Roy et al. 2015) and 2.1 ka at Argentière glacier (Le Roy 2012) and in the 306 Ecrins-Pelvoux massif (Le Roy et al. 2017). However, our data do not allow us to decide which 307 of the two hypotheses is more likely.

308 Fig. 5 shows the large YD/EH and LIA extents of Talèfre glacier in comparison to that 309 of 2008. During the YD/EH and the LIA, the glacier is still connected with the Mer de Glace, 310 and the LIA extent is only slightly smaller than that of the YD/EH, while in 2008 the glacier 311 size is significantly reduced.

We do not have any evidence of glacier advances between the EH and the Late 313 Holocene, which is consistent with a warmer and dryer climate, and thus unfavorable for glacier 314 growth in the Alps, during this period (Ivy-Ochs et al. 2009). Therefore, we assume that Talèfre 315 glacier was smaller than its LIA extent during this period.

317 Comparison with other Alpine glacier chronologies

319 The YD/Holocene chronology of Talèfre glacier is very similar to the one recently established 320 at the nearby Argentière glacier (Protin et al. 2019). A similar set of bedrock surfaces ( 2450 $321 \mathrm{~m}$ a.s.1.) and five lateral moraines ( 2400 - $2150 \mathrm{~m}$ a.s.1.), dated by in situ cosmogenic ${ }^{10} \mathrm{Be}$ to 322 between $\sim 11.7$ and $\sim 10.4 \mathrm{ka}$, provide evidence of deglaciation at the end of the YD and at least 323 five glacier re-advances or stillstands during the YD/EH transition. When comparing these two 324 age sets (Fig. 6D, E), it appears that the ages of the two outermost moraines of both glaciers are 325 undistinguishable within uncertainties, and that both glaciers oscillated several times during the $326 \mathrm{YD} / \mathrm{EH}$ transition. In this comparison, it must be kept in mind that T3 moraine of Talèfre glacier 327 could not be dated but seems to be only slightly younger than T1 and T2 moraines (see section 
328 "Moraine and bedrock exposure ages of Talèfre glacier") and might therefore be similar to the innermost EH ridge of Argentière glacier dated to $10.4 \pm 0.2 \mathrm{ka}$. These moraines of Talèfre and Argentière glaciers thus probably represent quasi-synchronous, successive glacier stillstands within the dynamic YD/EH retreat from their larger early-YD extents.

Moraines at multiple other locations across the Alps have previously been assigned to the YD/EH transition based on ${ }^{10} \mathrm{Be}$ dating. Eleven of them were selected here, based on their data quality (see section "Exposure ages of other Alpine chronologies"), together with our new Talèfre chronology for this regional compilation. They are geographically distributed across the European Alps (France, Switzerland, Italy and Austria), situated between longitudes $\sim 6.5^{\circ} \mathrm{E}$ and $10^{\circ} \mathrm{E}$ and latitudes $45.5^{\circ} \mathrm{N}$ and $47^{\circ} \mathrm{N}$ (Fig. 6). All of these twelve moraine chronologies indicate deposition of at least one moraine between $\sim 12$ and $\sim 10 \mathrm{ka}$ ago, i.e. during the YD/EH transition (Fig. 6). Further, at most sites, there is evidence of deposition of multiple lateral and/or latero-frontal moraines during this period. Successive moraines are located quite close to each other and in proximity to the LIA moraines, suggesting only slightly smaller glacier extents during the LIA than during the YD/EH compared to today's reduced glacier sizes like at Talèfre glacier (Fig. 5). The highest spatial spread is found at Arsine glacier displaying $\mathrm{YD} / \mathrm{EH}$ frontal moraines that are located about $1 \mathrm{~km}$ downstream of the LIA moraines (Schimmelpfennig et al. 2019). At several other sites in the Alps, lateral YD/EH moraines exist within $<300$ m-distance from lateral LIA moraines (Schimmelpfennig et al. 2012, 2014; Moran et al. 2016a; Hofmann 2018).

Thus, based on the consistency of the ${ }^{10} \mathrm{Be}$ cosmogenic exposure ages, we show here that millennial-scale synchronous glacier fluctuations occurred in the European Alps, and that glaciers oscillated multiple times at centennial or sub-centennial scale superposed on a general retreat trend during the 12-10 ka period. However, based on the available datasets it is not possible to temporally correlate specific moraines between sites or to give evidence of a decadal 
353 or centennial-scale synchroneity of glacier dynamics within the $\sim 12-10$ ka period, because of 354 (i) the analytical and geomorphic uncertainties related to the dating method; (ii) the probably 355 incomplete preservation of the moraine records or no deposition of the moraine; and (iii) 356 undated ridges within the investigated moraine sequences at several sites.

357 For the sites where ELA depressions between the YD/EH transition and the LIA have 358 been calculated using the Accumulation Area Ratio (AAR) method with a ratio of 0.67 (Table 359 S1), no significant correlations between moraine ages and ELA depressions are observed (Fig. $360 \mathrm{~S} 1$ ). In fact, the large range of ELA depressions supports the findings by Boxleitner et al. (2019) 361 that indicate ELA depressions should not be used to temporally correlate moraines from 362 different valleys, as previously proposed by Maisch (1981). This reflects the fact that ELA 363 variations of individual glaciers might be significantly influenced by local precipitation 364 amounts and local glacier morphology, as well as the limitations of the AAR method (e.g. 365 Reitner et al. 2016; Boxleitner et al. 2019).

367 Link of the Alpine glacier oscillations with regional climate

369 Analysis of the geographical characteristics of the 12 selected sites implies that their millennial 370 synchroneity is independent of their altitude range (at present between 1500 and $3400 \mathrm{~m}$ a.s.1.), 371 orientation (all directions) and size $\left(0.3\right.$ to $\left.14 \mathrm{~km}^{2}\right)$ (Fig. S1). In the absence of common 372 topographic characteristics of the glaciers, the only process to explain the millennial-scale 373 synchronous fluctuations of independent ice mass fluctuations across the European Alps is a 374 regional climatic signal that prevailed over local factors. Therefore, we compare here the 375 moraine chronologies with regional - and high-latitude - independent climate proxy records in 376 an effort to elucidate the spatial reach of the climatic evolution underlying the quasi377 simultaneous glacier oscillations across the European Alps within their dynamic retreat. 
378 Glaciers are sensitive to a variety of climatic factors, but the main driver for large-scale, long-

379 term glacier fluctuations in the mid- and high latitudes is the impact of summer temperature 380 variations (e.g. Oerlemans 2005; Solomina et al. 2015) on which we therefore focus. In 381 addition, over the last century, annual mass balance of Alpine glaciers was mainly driven by 382 summer melting (Huss et al. 2010). In the Alpine and pre-Alpine region, evidence of a 383 temperature minimum in the middle of the YD and several distinct cold events during a general 384 warming trend within the 12-10 ka period comes from various high-resolution palaeorecords 385 that reflect variations either in July air temperatures (based on chironomid-inferred records 386 from lakes in eastern France and the northern and central Swiss Alps; Heiri et al. 2015; Fig. $3876 \mathrm{~A}(3))$ or in mean annual temperatures, based on stable isotope measurements in stalagmites 388 (Wurth et al. 2004; Affolter et al. 2019; Fig. 6A(2)) and biogenically precipitated carbonates in 389 lake sediments (Schwander et al. 2000). These decadal to centennial cold peaks seem to have 390 amplitudes in the order of $\sim 0.5{ }^{\circ} \mathrm{C}$, i.e. similar to the multidecadal fluctuations that drove the 391 succession of LIA moraines in the Alps (Oerlemans 2005). Regional cold peaks could therefore 392 be sufficient to lead to the YD/EH succession of glacial culminations or still-stands during the 393 general deglaciation observed in the Alps. In this case, it is most likely that decadal to centennial 394 glacier oscillations occurred quasi-simultaneously across the Alps.

Link of the Alpine glacier extents with seasonality

398 It is remarkable that several glaciers around $12 \mathrm{ka}$ ago, i.e. at the end of the YD, were only 399 slightly larger than during the EH. This is the case for Rougnoux valley, Arsine, Talèfre, 400 Argentière, Tsidjiore Nouve, Belalp and Falgin Cirque glaciers, where the ages of the outermost 401 moraine fall into the YD or their uncertainties overlap with it (green probability curves in Fig. 402 6) and the ages of the innermost moraine fall into the EH. This small difference between late 
403 YD and EH glacier extents seems inconsistent with the drastic YD temperature cooling and 404 abrupt mean annual temperature increase that characterizes the boundary between these two 405 periods (Fig. 6A). A linear relationship between oxygen isotope record and temperature would 406 suggest that the coldest YD temperatures of the Greenland sites were only slightly higher than 407 those of the Last Glacial Maximum (e.g. Rasmussen et al. 2008) when Alpine glaciers reached 408 until the Alpine foreland (Ivy-Ochs et al. 2008). Much larger glacier extents might therefore be 409 expected during and at the end of the $\sim 1$ ka lasting YD, especially compared to the EH and 410 LIA. In addition, the ${ }^{10} \mathrm{Be}$ bedrock ages from outboard of the oldest dated moraines of Talèfre 411 and Argentière glaciers suggest that these glaciers have been retreating prior to the deposition 412 of their respective late YD moraine. These results are in line with ${ }^{10} \mathrm{Be}$-based glacier 413 chronologies from Greenland, also providing evidence of ice mass downwasting throughout the 414 YD, which lasted until the EH (Rainsley et al. 2018 and references therein).

415 The apparent mismatch between the glacier proxy records and the mean annual 416 temperature climate proxies could be due to a difference in seasonality between the YD and the 417 EH. This concept of seasonality was first proposed by Denton et al. (2005) to explain the 418 discord between the drastic change of the mean annual temperature observed in Greenland ice 419 cores and the slight snowline change of glaciers in Greenland and Europe during the YD and 420 EH. The YD, as well as other abrupt climate changes, has been qualified as a winter 421 phenomenon (Denton et al. 2005), meaning that the considerable annual temperature switches 422 observed in palaeoclimate records from Europe and Greenland are mainly due to changes in 423 winter temperature, while summer temperature did only undergo minor changes (Renssen \& 424 Isarin 2001; Buizert et al. 2014; Schenk et al. 2018).

425 In the Alpine region, a decrease of the seasonality between the YD and EH is supported 426 by the difference of mean annual and summer warming estimated from the above-mentioned 427 recent independent proxy studies (Heiri et al. 2015; Affolter et al. 2019; Fig. 6A(2, 3)). The 
428 stable isotope measurements in speleothems suggest an increase of the mean annual 429 temperature of $\sim 5.4{ }^{\circ} \mathrm{C}$ at the $\mathrm{YD} / \mathrm{EH}$ transition (Affolter et al. 2019; Fig. 6A(2)), while a 430 summer temperature increase of only $\sim 2.7{ }^{\circ} \mathrm{C}$ is inferred from the chironomid-based lake 431 records (Heiri et al. 2015; Fig. 6A(3)). This difference between annual and summer temperature 432 could be explained by a greater winter warming of more than $7^{\circ} \mathrm{C}$ if winter and summer periods 433 are assumed of equal duration. Furthermore, while the mean temperature increase in Greenland 434 occurred in less than one hundred years (Rasmussen et al. 2006; Fig. 6A(1)), the European 435 records indicate a more gradual warming distributed over several hundred years (Fig. 6A(2, 3)). 436 Our results support this concept, i.e. relatively mild YD summer temperatures could explain 437 why the glaciers in the Alps did not undergo a much more pronounced retreat at the YD/EH 438 transition, but glaciers retreated gradually from their only slightly larger YD extents.

$440 \quad$ Link of the Alpine glacier oscillations with high latitude climate

442 The clear correlation of high-resolution proxy records from the Alps and the Alpine foreland 443 (Heiri et al. 2015; Affolter et al. 2019; Fig. 6A(2, 3)) with the pattern of oxygen isotope 444 variations in Greenland ice cores (e.g. Rasmussen et al. 2006; Fig. 6A(1)) strongly suggests a 445 climatic link of the Alpine region with the northern high latitudes. In this context, a recent study 446 by Young et al. (2020) provides evidence of a succession of re-advances or stillstands of 447 mountain glaciers, the Laurentide Ice Sheet and Greenland Ice Sheet in the Baffin Bay region 448 at $\sim 11.8-11.6, \sim 10.4$ and $\sim 9.3 \mathrm{ka}$. The striking similarity of these moraine-based chronologies 449 from and near western Greenland with those from the European Alps provide further evidence 450 of a teleconnection between both regions at that time and that the observed glacier fluctuations 451 were due to a common climate evolution on extra-regional, maybe even hemispheric scale. 
The question arises which large-scale climate mechanisms led to this teleconnection and 453 the contrasted seasonality imprinted in the above-discussed summer temperature and mean 454 annual temperature records. The abrupt onset of the YD cooling and the cold peaks of the Late $455 \mathrm{YD}$ and $\mathrm{EH}$ in the high latitudes are thought to have been triggered by freshwater input from 456 the Laurentide Ice Sheet into the North Atlantic (Jennings et al. 2015) leading to a reduction of 457 the Atlantic Meridional Ocean Circulation (AMOC) (Renssen et al. 2015). The related 458 development of expanded wintertime sea ice in the North Atlantic shifted the westerlies south 459 leading to wind-transported cool temperatures to Europe (Brauer et al. 2008; Bakke et al. 2009), 460 and therefore to the Alps. During the second half of the YD, brief sea-ice breakups were led by 461 incursions of the Atlantic circulation and were associated with a northwards migration of the 462 polar front and westerly storm tracks (Bakke et al. 2009) until the system abruptly switched to 463 the interglacial state at the onset of the Holocene (Rasmussen et al. 2006). The signature of 464 these climatic mechanisms is markedly imprinted in the abrupt variations of the mean annual 465 temperature proxy records, but to a lesser degree in the glacier mass balance fluctuations. 466 Robust evidence of drastic glacier expansion in the Alps and the high latitudes in relation with 467 the strong annual cooling observed in the first part of the YD is rare so far. Early to mid-YD 468 moraines are preserved at a few sites in the Alps and at other sites in the North Atlantic region 469 (e.g. Belalp and Aletsch Glacier, Kelly et al. 2004; Schindelwig et al. 2012; Julier Pass, Ivy470 Ochs 2015; Alaska, Young et al. 2019; Norway, Wittmeier et al. 2020), but the corresponding 471 glacier extents were relatively modest compared to significant annual temperature decrease. In 472 addition, the deglaciation during the $\mathrm{YD} / \mathrm{EH}$ transition was rather gradual and punctuated by 473 closely-spaced short-lived re-advances or stillstands. This could be explained by several 474 mechanisms. Sea ice expansion occurs predominantly in winter and might therefore not directly 475 result in a summer temperature decrease. In addition, the drastic YD cooling recorded by the 476 mean annual temperature proxies was enhanced by an increased strength of wind only during 
477 autumn, winter and spring, which transported cold air from the ice-covered North Atlantic 478 region and led to cool and dry winters in Europe (Brauer et al. 2008). This phenomenon did not 479 occur during summer due to atmospheric blocking of the cold westerlies over Fennoscandia 480 leading to warm summers during the YD (Schenk et al. 2018). Therefore, and because snowfall 481 was reduced during the dry winters of the cold periods, greater glacier expansion did not occur 482 at many sites. Nevertheless, summers were very short, probably because winter sea ice 483 expansion lasted for a long period of the year, leading to a reduced glacier melt season (Young 484 et al. 2020). This might explain why glaciers responded with successive glacier advances or 485 stillstands to these dynamic changes in seasonality both in high latitudes and Europe.

\section{Conclusions}

Our new chronology based on $14{ }^{10} \mathrm{Be}$ cosmogenic exposure ages on moraine and bedrock from 490 the "Jardin de Talèfre" suggests that the central rock islet of the "Jardin de Talèfre" was deglaciated during the YD and that Talèfre glacier retreated from its YD position starting 12.4 ka ago. This retreat was interrupted by several episodes of stillstands before a major retreat 493 during the EH. No evidence of re-advances before the Late Holocene is recorded and the most 494 remarkable advance occurred during the LIA, which was only slightly less extensive than the 495 late YD and EH glacier extents at our high-elevation site. This behaviour is very similar to that of the nearby Argentière glacier. The comparison of the YD/EH transition moraine chronology 497 of Talèfre glacier with those of 11 other Alpine glaciers scattered throughout the Alps suggests 498 a period of roughly synchronous glacial behaviour across the Alps between 12 and 10 ka ago. 499 Several glaciers deposited multiple moraines, which attest to regional-scale stillstands or re500 advances during the deglaciation. Similarities with palaeotemperature records from the Alpine 501 region as well as with glacial culminations and temperature records from Greenland strongly 
502 suggest not only a regional common climate driver, but also a teleconnection with the high 503 latitudes, thus reinforcing the hypothesis postulated in earlier studies of a link between YD and 504 EH Alpine glacier fluctuations and Greenland climate change. However, the relatively small 505 amplitude of the YD glacier extents compared to the Holocene glacier extents is inconsistent 506 with the large and abrupt temperature shifts imprinted in mean annual proxy records in both 507 regions. We suggest that this inconsistency is due to a pronounced change in seasonality, with 508 YD winters cold and dry and YD summers only slightly cooler than those of the EH. This 509 seasonality difference controlled YD glacier extents and led to YD glaciers only slightly larger 510 than during the EH.

512 Acknowledgements. - This study is part of ANR 14-CE03-0006 VIP Mont-Blanc. We thank 513 Laëtitia Léanni (CEREGE) for support during chemistry and Jean Hanley and Roseanne 514 Schwartz (LDEO, Columbia University) for advices on sample chemistry and Joerg Schaefer 515 (LDEO, Columbia University) for discussion. The ASTER AMS national facility (CEREGE) 516 is supported by the INSU/CNRS, the ANR through the "projet thématiques d'excellence" 517 program for the "Equipements d'excellence" ASTER-CEREGE action and IRD. An earlier 518 version of this manuscript greatly benefitted from constructive comments by Benjamin 519 Chandler. We thank Marie Chenet and an anonymous reviewer whose relevant comments have 520 helped to improve this manuscript.

522 Author contributions. - JLM, IS, JFB and BP acquired the funding for the project leading to this 523 publication. MP, JLM, JFB, BP and LM conducted the fieldwork. MP carried out the laboratory 524 work. ASTER Team realized the AMS measurements. MP, IS, JLM and MLR did the data 525 analysis and prepared the original draft of the manuscript and all co-authors contributed the 526 final draft of the manuscript. 
528 Data availability. - The data that support the findings of this study are available from the 529 corresponding author upon reasonable request.

531 References

532 Affolter, S., Häuselmann, A., Fleitmann, D., Edwards, R. L., Cheng, H. \& Leuenberger, M. 533 534 535 2019: Central Europe temperature constrained by speleothem fluid inclusion water isotopes over the past 14,000 years. Science Advances 5, eaav3809, https://doi.org/10.1126/sciadv.aav3809.

André, M. 2002: Rates of postglacial rock weathering on glacially scoured outcrops (abiskoriksgränsen area, $\left.68^{\circ} \mathrm{n}\right)$. Geografiska Annaler: Series A, Physical Geography 84, 139150.

539 Arnold, M., Merchel, S., Bourlès, D. L., Braucher, R., Benedetti, L., Finkel, R.C., Aumaître, 540 G., Gottdang, A. \& Klein, M. 2010: The French accelerator mass spectrometry facility 541 ASTER: Improved performance and developments. Nuclear Instruments and Methods in $542 \quad$ Physics Research Section B: Beam Interactions with Materials and Atoms 268, 1954543 1959.

544 Bakke, J., Lie, Ø., Heegaard, E., Dokken, T., Haug, G. H., Birks, H. H., Dulski, P. \& Nilsen, 545 T. 2009: Rapid oceanic and atmospheric changes during the Younger Dryas cold period. $546 \quad$ Nature Geoscience 2, 202-205.

547 Balco, G., Stone, J. O., Lifton, N. A. \& Dunai, T. J. 2008: A complete and easily accessible 548 means of calculating surface exposure ages or erosion rates from ${ }^{10} \mathrm{Be}$ and ${ }^{26} \mathrm{Al}$ 549 measurements. Quaternary Geochronology 3, 174-195.

550 Balco, G., Briner, J., Finkel, R. C., Rayburn, J. A., Ridge, J. C. \& Schaefer, J. M. 2009: Regional 551 beryllium-10 production rate calibration for late-glacial northeastern North America. 
552

553

554

555

556

557

558

559

560

561

562

563

564

565

566

567

568

569

570

571

572

573

574

575

576

Quaternary Geochronology 4, 93-107.

Balco, G. 2017: Production rate calculations for cosmic-ray-muon-produced ${ }^{10} \mathrm{Be}$ and ${ }^{26} \mathrm{Al}$ benchmarked against geological calibration data. Quaternary Geochronology 39, 150173.

Baroni, C., Casale, S., Salvatore, M. C., Ivy-Ochs, S., Christl, M., Carturan, L., Seppi, R. \& Carton, A. 2017: Double response of glaciers in the Upper Peio Valley (Rhaetian Alps, Italy) to the Younger Dryas climatic deterioration. Boreas 46, 783-798.

Borchers, B., Marrero, S., Balco, G., Caffee, M., Goehring, B., Lifton, N., Nishiizumi, K., Phillips, F., Schaefer, J. \& Stone, J. 2016: Geological calibration of spallation production rates in the CRONUS-Earth project. Quaternary Geochronology 31, 188-198.

Boxleitner, M., Ivy-Ochs, S., Egli, M., Brandova, D., Christl, M. \& Maisch, M. 2019: Lateglacial and Early Holocene glacier stages - New dating evidence from the Meiental in central Switzerland. Geomorphology 340, 15-31.

Braucher, R., Guillou, V., Bourlès, D. L., Arnold, M., Aumaître, G., Keddadouche, K. \& Nottoli, E. 2015: Preparation of ASTER in-house ${ }^{10} \mathrm{Be} /{ }^{9} \mathrm{Be}$ standard solutions. Nuclear Instruments and Methods in Physics Research Section B: Beam Interactions with Materials and Atoms 361, 335-340.

Brauer, A., Haug, G. H., Dulski, P., Sigman, D. M. \& Negendank, J. F. W. 2008: An abrupt wind shift in western Europe at the onset of the Younger Dryas cold period. Nature Geoscience 1, 520-523.

Braumann, S. M., Schaefer, J. M., Neuhuber, S. M., Reitner, J. M., Lüthgens, C. \& Fiebig, M. 2020: Holocene glacier change in the Silvretta Massif (Austrian Alps) constrained by a new ${ }^{10} \mathrm{Be}$ chronology, historical records and modern observations. Quaternary Science Reviews 245, 106493, https://doi.org/10.1016/j.quascirev.2020.106493.

Buizert, C., Gkinis, V., Severinghaus, J. P., He, F., Lecavalier, B. S., Kindler, P., Leuenberger, 
M., Carlson, A. E., Vinther, B., Masson-Delmotte, V., White, J. W. C., Liu, Z., OttoBliesner, B. \& Brook, E. J. 2014: Greenland temperature response to climate forcing during the last deglaciation. Science 345, 1177-1180.

Bussy, F., Hernandez, J. \& Raumer, J. V. 2000. Bimodal magmatism as a consequence of the post-collisional readjustment of the thickened Variscan continental lithosphere (Aiguilles Rouges-Mont Blanc Massifs, Western Alps). Earth and Environmental Science Transactions of the Royal Society of Edinburgh 91, 221-233.

Chenet, M., Brunstein, D., Jomelli, V., Roussel, E., Rinterknecht, V., Mokadem, F., Biette, M., Robert, V. \& Léanni, L. 2016: ${ }^{10} \mathrm{Be}$ cosmic-ray exposure dating of moraines and rock avalanches in the Upper Romanche valley (French Alps): Evidence of two glacial advances during the Late Glacial/Holocene transition. Quaternary Science Reviews 148, 209-221.

Chmeleff, J., von Blanckenburg, F., Kossert, K. \& Jakob, D. 2010: Determination of the ${ }^{10} \mathrm{Be}$ half-life by multicollector ICP-MS and liquid scintillation counting. Nuclear Instruments and Methods in Physics Research Section B: Beam Interactions with Materials and Atoms 268, 192-199.

Claude, A., Ivy-Ochs, S., Kober, F., Antognini, M., Salcher, B. \& Kubik, P. W. 2014: The Chironico landslide (Valle Leventina, southern Swiss Alps): age and evolution. Swiss Journal of Geosciences 107, 273-291.

Cossart, E., Fort, M., Bourlès, D., Braucher, R., Perrier, R. \& Siame, L. 2012: Deglaciation pattern during the Lateglacial/Holocene transition in the southern French Alps. Chronological data and geographical reconstruction from the Clarée Valley (upper Durance catchment, southeastern France). Palaeogeography, Palaeoclimatology, Palaeoecology 315-316, 109-123.

de Decker Heftler, S. 2002: Photographier le Mont Blanc. 171 pp. Editions Guérin, Chamonix. 
602 Denton, G., Alley, R., Comer, G. \& Broecker, W. 2005: The role of seasonality in abrupt 603 climate change. Quaternary Science Reviews 24, 1159-1182.

604 Fischer, M., Huss, M., Barboux, C. \& Hoelzle, M. 2014: The New Swiss Glacier Inventory 605 606 SGI2010: Relevance of Using High-Resolution Source Data in Areas Dominated by Very Small Glaciers. Arctic, Antarctic, and Alpine Research 46, 933-945.

607 Gardent, M. 2014: Inventaire et retrait des glaciers dans les alpes françaises depuis la fin du $608 \quad$ Petit Age Glaciaire. Ph.D. thesis, Université de Grenoble, 444 pp.

609 Gardent, M., Rabatel, A., Dedieu, J.-P. \& Deline, P. 2014: Multitemporal glacier inventory of 610 the French Alps from the late 1960s to the late 2000s. Global and Planetary Change 120, $611 \quad 24-37$.

612 Heiri, O., Ilyashuk, B., Millet, L., Samartin, S. \& Lotter, A. F. 2015: Stacking of discontinuous 613 regional palaeoclimate records: Chironomid-based summer temperatures from the Alpine 614 region. The Holocene 25, 137-149.

615 Hofmann, F. M. 2018: Glacial history of the upper Drac Blanc catchment (Écrins massif, 616 French Alps). E\&G Quaternary Science Journal 67, 37-40.

617 Huss, M., Hock, R., Bauder, A. \& Funk, M. 2010: 100-year mass changes in the Swiss Alps 618 linked to the Atlantic Multidecadal Oscillation. Geophysical Research Letters 37, 619 https://doi.org/10.1029/2010GL042616.

620 Ivy-Ochs, S. 2015: Glacier variations in the European Alps at the end of the last glaciation. 621 Cuadernos de Investigación Geográfica 41, 295-315.

622 Ivy-Ochs, S., Kerschner, H., Reuther, A., Maisch, M., Sailer, R., Schaefer, J., Kubik, P. W., 623 Synal, H.-A. \& Schlüechter, C. 2006: The timing of glacier advances in the northern 624 European Alps based on surface exposure dating with cosmogenic ${ }^{10} \mathrm{Be},{ }^{26} \mathrm{Al},{ }^{36} \mathrm{Cl}$, and $625{ }^{21}$ Ne. In Alonso-Zarza, A. M. \& Tanner, L. H. (eds.): In Situ-Produced Cosmogenic 626 Nuclides and Quantification of Geological Processes, 43- 60. Geological Society of 
627

628

629

630

631

632

633

634

635

636

637

638

639

640

641

642

643

644

645

646

647

648

649

650

651

America, Boulder.

Ivy-Ochs, S., Kerschner, H., Reuther, A., Preusser, F., Heine, K., Maisch, M., Kubik, P. W. \& Schlüchter, C. 2008: Chronology of the last glacial cycle in the European Alps. Journal of Quaternary Science 23, 559-573.

Ivy-Ochs, S., Kerschner, H., Maisch, M., Christl, M., Kubik, P. W. \& Schlüchter, C. 2009: Latest Pleistocene and Holocene glacier variations in the European Alps. Quaternary Science Reviews 28, 2137-2149.

Jennings, A., Andrews, J., Pearce, C., Wilson, L. \& Ólfasdótttir, S. 2015: Detrital carbonate peaks on the Labrador shelf, a 13-7ka template for freshwater forcing from the Hudson Strait outlet of the Laurentide Ice Sheet into the subpolar gyre. Quaternary Science Reviews 107, 62-80.

Joly, D., Berger, A., Buoncristiani, J.-F., Champagne, O., Pergaud, J., Richard, Y., Soare, P. \& Pohl, B. 2018: Geomatic downscaling of temperatures in the Mont Blanc massif: A NEW STATISTICAL DOWNSCALING APPROACH. International Journal of Climatology $38,1846-1863$.

Jordan, D. 2010: Le Jardin de Talèfre dans le massif du Mont-Blanc à Chamonix - Réévaluation et contribution à sa connaissance botanique. Le Monde des Plantes 501, 9-20.

Kelly, M. A., Kubik, P. W., Von Blanckenburg, F. \& Schlüchter, C. 2004: Surface exposure dating of the Great Aletsch Glacier Egesen moraine system, western Swiss Alps, using the cosmogenic nuclide ${ }^{10}$ Be. Journal of Quaternary Science 19, 431-441.

Kerschner, H., Hertl, A., Gross, G., Ivy-Ochs, S. \& Kubik, P. W. 2006: Surface exposure dating of moraines in the Kromer valley (Silvretta Mountains, Austria)-evidence for glacial response to the $8.2 \mathrm{ka}$ event in the Eastern Alps? The Holocene 16, 7-15.

Kobashi, T., Severinghaus, J. P. \& Barnola, J.-M. 2008: $4 \pm 1.5^{\circ} \mathrm{C}$ abrupt warming $11,270 \mathrm{yr}$ ago identified from trapped air in Greenland ice. Earth and Planetary Science Letters 
652

653

654

655

656

657

658

659

660

661

662

663

664

665

666

667

668

669

670

671

672

673

674

675

676

268, 397-407.

Korschinek, G., Bergmaier, A., Faestermann, T., Gerstmann, U. C., Knie, K., Rugel, G., Wallner, A., Dillmann, I., Dollinger, G., von Gostomski, Ch. L., Kossert, K., Maiti, M., Poutivtsev, M. \& Remmert, A. 2010: A new value for the half-life of ${ }^{10}$ Be by Heavy-Ion Elastic Recoil Detection and liquid scintillation counting. Nuclear Instruments and Methods in Physics Research Section B: Beam Interactions with Materials and Atoms $268,187-191$.

Le Roy, M. 2012: Reconstitution des fluctuations glaciaires Holocènes dans les Alpes occidentales: apports de la dendrochronologie et de la datation par isotopes cosmogéniques produits in situ. Ph.D. thesis, Université Grenoble Alpes, 363 pp.

Le Roy, M., Nicolussi, K., Deline, P., Astrade, L., Edouard, J.-L., Miramont, C. \& Arnaud, F. 2015: Calendar-dated glacier variations in the western European Alps during the Neoglacial: the Mer de Glace record, Mont Blanc massif. Quaternary Science Reviews $108,1-22$.

Le Roy, M., Deline, P., Carcaillet, J., Schimmelpfennig, I. \& Ermini, M. 2017: ${ }^{10}$ Be exposure dating of the timing of Neoglacial glacier advances in the Ecrins-Pelvoux massif, southern French Alps. Quaternary Science Reviews 178, 118-138.

Lotter, A. F., Birks, H. J. B., Eicher, U., Hofmann, W., Schwander, J. \& Wick, L. 2000: Younger Dryas and Allerød summer temperatures at Gerzensee (Switzerland) inferred from fossil pollen and cladoceran assemblages. Palaeogeography, Palaeoclimatology, Palaeoecology 159, 349-361.

Maisch, M. 1981: Glazialmorphologische und gletschergeschichtliche Untersuchungen im Gebiet zwischen Landwasser- und Albulatal (Kt. Graubünden, Schweiz). Ph.D. thesis, Universität Zürich, 215 pp. 
677

678

679

680

681

682

683

684

685

686

687

688

689

690

691

692

693

694

695

696

697

698

699

700

701

divergent trends and millennial variations in Holocene temperatures. Nature 554, 92-96.

Martin, L. C. P., Blard, P.-H., Balco, G., Lavé, J., Delunel, R., Lifton, N. \& Laurent, V. 2017: The CREp program and the ICE-D production rate calibration database: A fully parameterizable and updated online tool to compute cosmic-ray exposure ages. Quaternary Geochronology 38, 25-49.

Merchel, S., Arnold, M., Aumaître, G., Benedetti, L., Bourlès, D. L., Braucher, R., Alfimov, V., Freeman, S. P. H. T., Steier, P. \& Wallner, A. 2008: Towards more precise ${ }^{10} \mathrm{Be}$ and ${ }^{36} \mathrm{Cl}$ data from measurements at the 10-14 level: Influence of sample preparation. Nuclear Instruments and Methods in Physics Research Section B: Beam Interactions with Materials and Atoms 266, 4921-4926.

Moran, A. P., Ivy-Ochs, S., Schuh, M., Christl, M. \& Kerschner, H. 2016a: Evidence of central Alpine glacier advances during the Younger Dryas-early Holocene transition period. Boreas 45, 398-410.

Moran, A. P., Kerschner, H. \& Ochs, S. I. 2016b: Redating the moraines in the Kromer Valley (Silvretta Mountains)-New evidence for an early Holocene glacier advance. The Holocene 26, 655-664.

Oerlemans, J. 2005: Extracting a climate signal from 169 glacier records. Science 308, 675677.

Protin, M., Schimmelpfennig, I., Mugnier, J.-L., Ravanel, L., Le Roy, M., Deline, P., Favier, V., Buoncristiani, J.-F. \& ASTER Team 2019: Climatic reconstruction for the Younger Dryas/Early Holocene transition and the Little Ice Age based on paleo-extents of Argentière glacier (French Alps). Quaternary Science Reviews 221, 105863, https://doi.org/10.1016/j.quascirev.2019.105863.

Prud'homme, C., Vassallo, R., Crouzet, C., Carcaillet, J., Mugnier, J.-L. \& Cortés-Aranda, J. 2020: Paired ${ }^{10}$ Be sampling of polished bedrock and erratic boulders to improve dating 
702

703

704

705

706

707

708

709

710

711

712

713

714

715

716

717

718

719

720

721

722

723

724

725

726

of glacial landforms: an example from the Western Alps. Earth Surface Processes and Landforms 45, 1168-1180.

Putnam, A. E., Bromley, G. R. M., Rademaker, K. \& Schaefer, J. M. 2019: In situ ${ }^{10}$ Be production-rate calibration from a ${ }^{14} \mathrm{C}$-dated late-glacial moraine belt in Rannoch Moor, central Scottish Highlands. Quaternary Geochronology 50, 109-125.

Rabatel, A., Letréguilly, A., Dedieu, J.-P. \& Eckert, N. 2013: Changes in glacier equilibriumline altitude in the western Alps from 1984 to 2010: evaluation by remote sensing and modeling of the morpho-topographic and climate controls. The Cryosphere 7, 14551471.

Rainsley, E., Menviel, L., Fogwill, C. J., Turney, C. S. M., Hughes, A. L. C. \& Rood, D. H. 2018: Greenland ice mass loss during the Younger Dryas driven by Atlantic Meridional Overturning Circulation feedbacks. Scientific Reports 8, 11307, https://doi.org/10.1038/s41598-018-29226-8.

Rasmussen, S. O., Andersen, K. K., Svensson, A. M., Steffensen, J. P., Vinther, B. M., Clausen, H. B., Siggaard-Andersen, M. L., Johnsen, S. J., Larsen, L. B., Dahl-Jensen, D., Bigler, M., Rothlisberger, R., Fischer, H., Goto-Azuma, K., Hansson, M. E. \& Ruth, U. 2006: A new Greenland ice core chronology for the last glacial termination. Journal of Geophysical Research - Atmospheres 111, D06102, https://doi.org/10.1029/2005JD006079.

Rasmussen, S. O., Seierstad, I. K., Andersen, K. K., Bigler, M., Dahl-Jensen, D., Johnsen \& S. J. 2008: Synchronization of the NGRIP, GRIP, and GISP2 ice cores across MIS 2 and palaeoclimatic implications. Quaternary Science Reviews 27, 18-28.

Reitner, J. M., Ivy Ochs, S., Dreschner-Schneider, R., Hajdas, I. \& Linner, M. 2016: Reconsidering the current stratigraphy of the Alpine Lateglacial: Implications of the sedimentary and morphological record of the Lienz area (Tyrol/Austria). E\&G 
Quaternary Science Journal 65, 113-144.

Renssen, H. \& Isarin, R. F. B. 2001: The two major warming phases of the last deglaciation at $\sim 14.7$ and $\sim 11.5$ ka cal BP in Europe: climate reconstructions and AGCM experiments. Global and Planetary Change 30, 117-153.

Renssen, H., Mairesse, A., Goosse, H., Mathiot, P., Heiri, O., Roche, D. M., Nisancioglu, K. H. \& Valdes, P. J. 2015: Multiple causes of the Younger Dryas cold period. Nature Geoscience 8, 946-949.

Roe, G. H., Baker, M. B. \& Herla, F. 2017: Centennial glacier retreat as categorical evidence of regional climate change. Nature Geoscience 10, 95-99.

Schenk, F., Väliranta, M., Muschitiello, F., Tarasov, L., Heikkilä, M., Björck, S., Brandefelt, J., Johansson, A. V., Näslund, J.-O. \& Wohlfarth, B. 2018: Warm summers during the Younger Dryas cold reversal. Nature Communications 9, 1634, https://doi.org/10.1038/s41467-018-04071-5.

Schimmelpfennig, I., Schaefer, J. M., Goehring, B. M., Lifton, N., Putnam, A. E. \& Barrell, D. J. A. 2012: Calibration of the in situ cosmogenic ${ }^{14} \mathrm{C}$ production rate in New Zealand's Southern Alps. Journal of Quaternary Science 27, 671-674.

Schimmelpfennig, I., Schaefer, J. M., Akçar, N., Koffman, T., Ivy-Ochs, S., Schwartz, R., Finkel, R. C., Zimmerman, S. \& Schlüchter, C. 2014: A chronology of Holocene and Little Ice Age glacier culminations of the Steingletscher, Central Alps, Switzerland, based on high-sensitivity beryllium-10 moraine dating. Earth and Planetary Science Letters $393,220-230$.

Schimmelpfennig, I., Le Roy, M., Deline, P., Schoeneich, P., Carcaillet, J., Bodin, X. \& ASTER Team 2019: Holocene dynamics of Arsine glacier (Ecrins massif, French Alps) inferred from dating. Abstract, INQUA conference, Dublin. https://doi.org/10.13140/RG.2.2.10849.86884. 
752 Schindelwig, I., Akçar, N., Kubik, P. W. \& Schlüchter, C. 2012: Lateglacial and early Holocene 753 dynamics of adjacent valley glaciers in the Western Swiss Alps. Journal of Quaternary Science 27, 114-124.

755

756

757

758

759

760

761

762

763

764

765

766

767

768

769

770

771

772

773

774

775

776

Schwander, J., Eicher, U. \& Ammann, B. 2000: Oxygen isotopes of lake marl at Gerzensee and Leysin (Switzerland), covering the Younger Dryas and two minor oscillations, and their correlation to the GRIP ice core. Palaeogeography, Palaeoclimatology, Palaeoecology $159,203-214$.

Shakun, J. D., Clark, P. U., He, F., Lifton, N.A., Liu, Z. \& Otto-Bliesner, B. L. 2015: Regional and global forcing of glacier retreat during the last deglaciation. Nature Commununications 6, 8059, https://doi.org/10.1038/ncomms9059.

Smiraglia, C., Azzoni, R. S., D’Agata, C., Maragno, D., Fugazza, D. \& Diolaiuti, G. A. 2015: The evolution of the Italian glaciers from the previous data base to the New Italian Inventory. Preliminary considerations and results. Geografia Fisica e Dinamica Quaternaria 38, 79-87.

Solomina, O. N., Bradley, R. S., Hodgson, D. A., Ivy-Ochs, S., Jomelli, V., Mackintosh, A. N., Nesje, A., Owen, L. A., Wanner, H., Wiles, G. C. \& Young, N. E. 2015: Holocene glacier fluctuations. Quaternary Science Reviews 111, 9-34.

Vincent, C., Fischer, A., Mayer, C., Bauder, A., Galos, S. P., Funk, M., Thibert, E., Six, D., Braun, L. \& Huss, M. 2017: Common climatic signal from glaciers in the European Alps over the last 50 years. Geophysical Research Letters 44, 1376-1383.

Vinther, B. M., Clausen, H. B., Johnsen, S. J., Rasmussen, S. O., Andersen, K. K., Buchardt, S. L., Dahl-Jensen, D., Seierstad, I. K., Siggaard-Andersen, M.-L., Steffensen, J. P., Svensson, A., Olsen, J. \& Heinemeier, J. 2006: A synchronized dating of three Greenland ice cores throughout the Holocene. Journal of Geophysical Research - Atmospheres 111, D13102, https://doi.org/10.1029/2005JD006921. 
777 Ward, G. K. \& Wilson, S. R. 1978: Procedures for comparing and combining radiocarbon age

778

779

780

781

782

783

784

785

786

787

788

789

790

791

792

793

794

795 determinations: a critique. Archaeometry 20, 19-31.

Wittmeier, H. E., Schaefer, J. M., Bakke, J., Rupper, S., Paasche, Ø., Schwartz, R. \& Finkel, R. C. 2020: Late Glacial mountain glacier culmination in Arctic Norway prior to the Younger Dryas. Quaternary Science Reviews 245, 106461, doi: 10.1016/j.quascirev.2020.106461.

Wurth, G., Niggemann, S., Richter, D. K. \& Mangini, A. 2004: The Younger Dryas and Holocene climate record of a stalagmite from Hölloch Cave (Bavarian Alps, Germany). Journal of Quaternary Science 19, 291-298.

Young, N. E., Schaefer, J. M., Briner, J. P. \& Goehring, B. M. 2013. A ${ }^{10}$ Be production-rate calibration for the Arctic. Journal of Quaternary Science 28, 515-526.

Young, N. E., Briner, J. P., Schaefer, J., Zimmerman, S. \& Finkel, R. C. 2019: Early Younger Dryas glacier culmination in southern Alaska: Implications for North Atlantic climate change during the last deglaciation. Geology 47, 550-554.

Young, N. E., Briner, J. P., Miller, G. H., Lesnek, A. J., Crump, S. E., Thomas, E. K., Pendleton, S. L., Cuzzone, J., Lamp, J., Zimmerman, S., Caffee, M. \& Schaefer, J. M. 2020: Deglaciation of the Greenland and Laurentide ice sheets interrupted by glacier advance during abrupt coolings. Quaternary Science Reviews 229, 106091, https://doi.org/10.1016/j.quascirev.2019.106091. 


\section{Legends}

797 Fig. 1. Location of Talèfre glacier and study area: the "Jardin de Talèfre". A. Location of the

798 Mont Blanc massif (red dot) in the Alps (red dotted line). B. The Mont Blanc massif and 799 present-day glacier extents on a Landsat 8 image (April 2015); French glaciers: Gardent et al. 800 (2014); Swiss glaciers: Fischer et al. (2014); Italian glaciers: Smiraglia et al. (2015). Talèfre 801 glacier is highlighted in dark blue, the "Jardin de Talèfre" is located in the red square. 802

803 Fig. 2. A. Photograph of the "Jardin de Talèfre" in 1890 (source: "Les Amis du Vieux 804 Chamonix"). B. Oblique aerial imagery of the "Jardin de Talèfre" in September 2016. Talèfre 805 glacier is highlighted in light blue, sampled moraines T1 and T2 (dark blue) and Holocene 806 moraines, including T4 (purple) are shown. Bedrock sample locations are shown as red dots 807 and some of the sampled boulders as green dots (photograph by J.-F. Buoncristiani). C. 808 Example of sampled bedrock surface. D. Example of sampled boulder on T2 moraine. 809

810 Fig. 3. Moraines and sample locations in the "Jardin de Talèfre", mapped on the $5 \mathrm{~m}$ IGN DEM 811 RGE ALTI and aerial images. Present-day glacier extent (in blue) is from Gardent et al. (2014).

812 Dashed lines represent undated moraines, the age of which is assumed according to their 813 relative position and morphology. Individual surface exposure ages are listed in the white boxes 814 with their analytical uncertainties and mean ages of the landforms in the colored bands 815 (arithmetic means and standard deviations). Outliers are in italic grey font.

816

817 Fig. 4. Probability plots of the individual moraine sample ages (black curves, analytical 818 uncertainty only) from Talèfre glacier. Colored curves, vertical lines and bands represent the 
819 summed probability plots, arithmetic means and standard deviations, respectively, 820 corresponding to the age labeled in each box, only calculated for T1 and T2.

821

822 Fig. 5. Reconstruction of past extents of Talèfre glacier, based on mapping of the preserved 823 moraines and interpretation of ${ }^{10} \mathrm{Be}$ dating, for the Younger Dryas/Early Holocene transition 824 (A) (12 ka, stage T1 moraine), LIA maximum (B) and $2008 \mathrm{CE}$ (C) (Gardent et al. 2014). 825 Dashed glacier limits correspond to hypothetic extents.

826

827 Fig. 6. Chronology of culminations of Talèfre glacier based on the ${ }^{10} \mathrm{Be}$ mean ages of the glacial 828 landforms in this study (D) compared to independent palaeoclimate records (A) and to other 829 glacier chronology studies in the Alps also using ${ }^{10} \mathrm{Be}$ moraine dating (B-M). Each moraine is 830 represented by a summed probability curve along with the number of dated boulders $(n=x)$, 831 vertical lines and colored band represent the arithmetic means and standard deviations $(1 \sigma)$, 832 colors represent the stratigraphic order of the moraines (from outer to inner: green, blue, purple, 833 pink). A(1). Oxygen isotope record in Greenland ice core NGRIP (Rasmussen et al. 2006;

834 Vinther et al. 2006), blue bands represent the Younger Dryas and cold peaks during the Early 835 Holocene as identified in the Greenland ice core record. A(2). Oxygen isotope record from 836 speleotem fluid inclusion from Milandre cave, Switzerland (Affolter et al. 2019). A(3). Stacked 837 chironomid-inferred July air temperature from the Alps (Heiri et al. 2015), black arrows point 838 to peaks mentioned in the main text. Alpine glacier sites in panels B, C and E to $\mathrm{M}$ are presented 839 from east to west with their locations shown by red dots on the map. B. Rougnoux valley 840 (Hofmann 2018). C. Arsine glacier (Schimmelpfennig et al. 2019). E. Argentière glacier (Protin 841 et al. 2019). F. Tsidjiore Nouve glacier (Schimmelpfennig et al. 2012). G. Belalp cirque 842 (Schindelwig et al. 2012). H. Steingletscher (Schimmelpfennig et al. 2014). I. Kromer valley 843 (Kerschner et al. 2006; Moran et al. 2016b). J. Kloster valley (Moran et al. 2016b). K. Falgin 
844 glacier (Moran et al. 2016a). L. La Mare glacier (Baroni et al. 2017). M. Careser glacier (Baroni 845 et al. 2017). Vertical dashed lines delimit the YD/EH transition period between 12 and $10 \mathrm{ka}$.

Table 1. Characteristics and ${ }^{10} \mathrm{Be}$ measurement details of samples and blanks measured in this study. Outliers are highlighted by $(\mathrm{O})$. Results of the exposure ages are presented using both 849 the regional production rate (Claude et al. 2014) and the "Artic" production rate (Young et al. 850 2013). Exposure ages are indicated with external uncertainties and internal uncertainties 851 (including the ${ }^{10} \mathrm{Be}$ production rate uncertainty) in parentheses. Mean landform ages of $\mathrm{T} 1$ and $852 \mathrm{~T} 2$ are indicated with standard deviations and total uncertainties (including the ${ }^{10} \mathrm{Be}$ production 853 rate uncertainty) in parentheses.

Supporting Information

Fig. S1. Geographic characteristics of the Alpine glaciers selected for the comparison and 859 presented in Fig. 6 and comparison of ELA depression (relative to LIA). A. Wind rose 860 indicating the orientation of each glacier. B. Graph representing the present-day length of the 861 glaciers versus their maximum and minimum elevation. C. ELA depression (relative to LIA, 862 calculated with the AAR methods and 0.67 ratio) versus the age of the studied stadial. Letters 863 correspond to panels and locations in Fig. 6. As Rougnoux glacier (Hofmann 2018) has now 864 disappeared, it is not represented in A and B.

866 Table S1. ${ }^{10} \mathrm{Be}$ exposure ages from the previously published moraine records in the Alps that 867 were considered in the comparison with the moraine ages from Talèfre glacier and associated 868 ELA depressions (relative to LIA) when calculated in the original study. For comparison, all 
869 ages were calculated using the same method as applied for the Talèfre samples (see "Age 870 calculations"). Outliers (O) were determined either based on original authors choice or on the $871 \chi^{2}$ test $(2 \sigma)$ as applied to the ages from Talèfre moraines. For samples from Cossart et al. 872 (2012), a sample thickness of $2 \mathrm{~cm}$ was assumed as this information is not given in the original 873 paper. When not specified by authors, we assumed a rock density of $2.7 \mathrm{~g} \mathrm{~cm}^{-3}$. Sites or 874 moraines that do not fulfill the selection criteria detailed in the main text are in italic while sites 875 that met the selection criteria for comparison are in bold. Capital letters in parentheses 876 correspond to panels and location in Fig. 6. ELA are calculated with the AAR method and a $877 \quad 0.67$ ratio. 


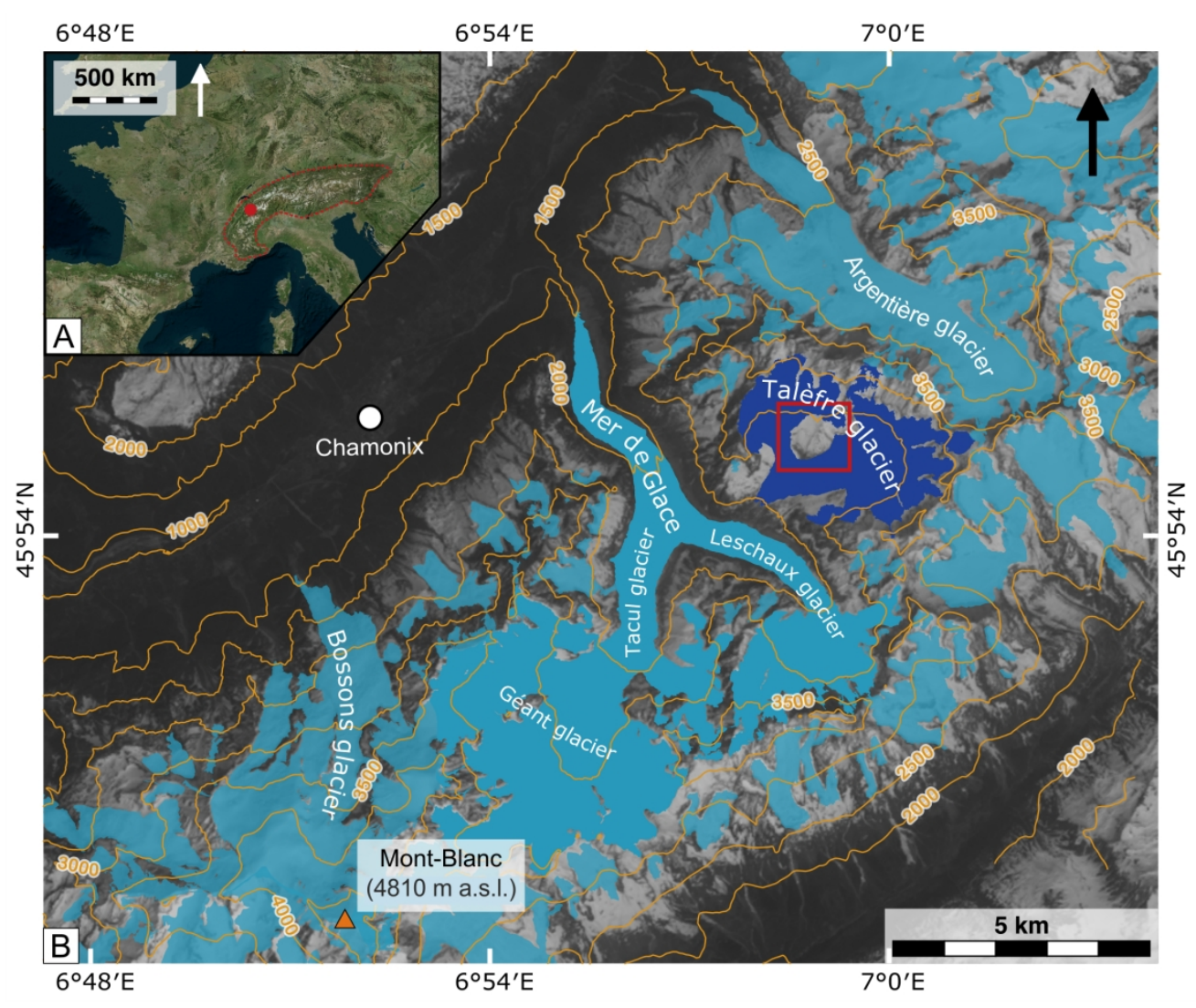




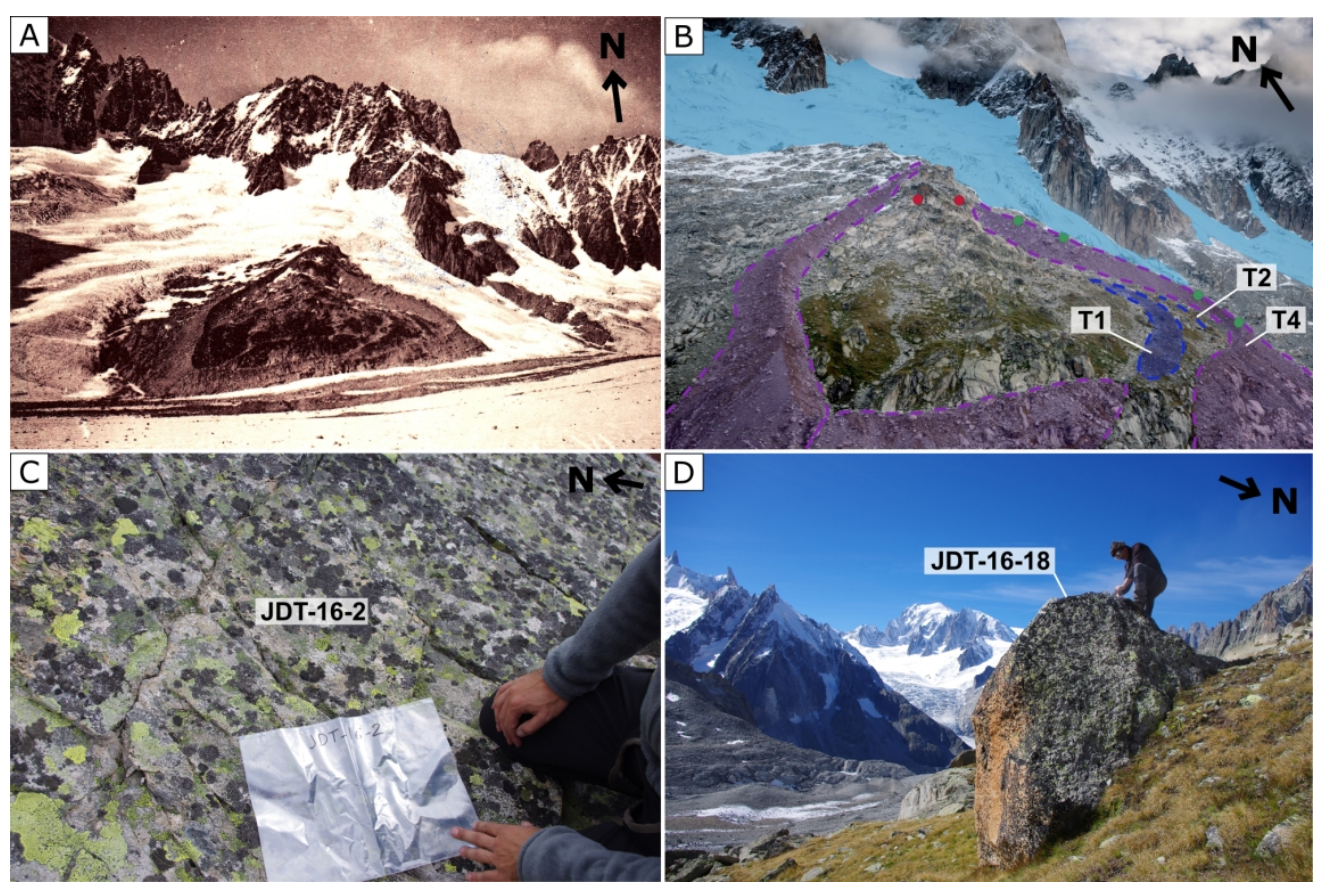




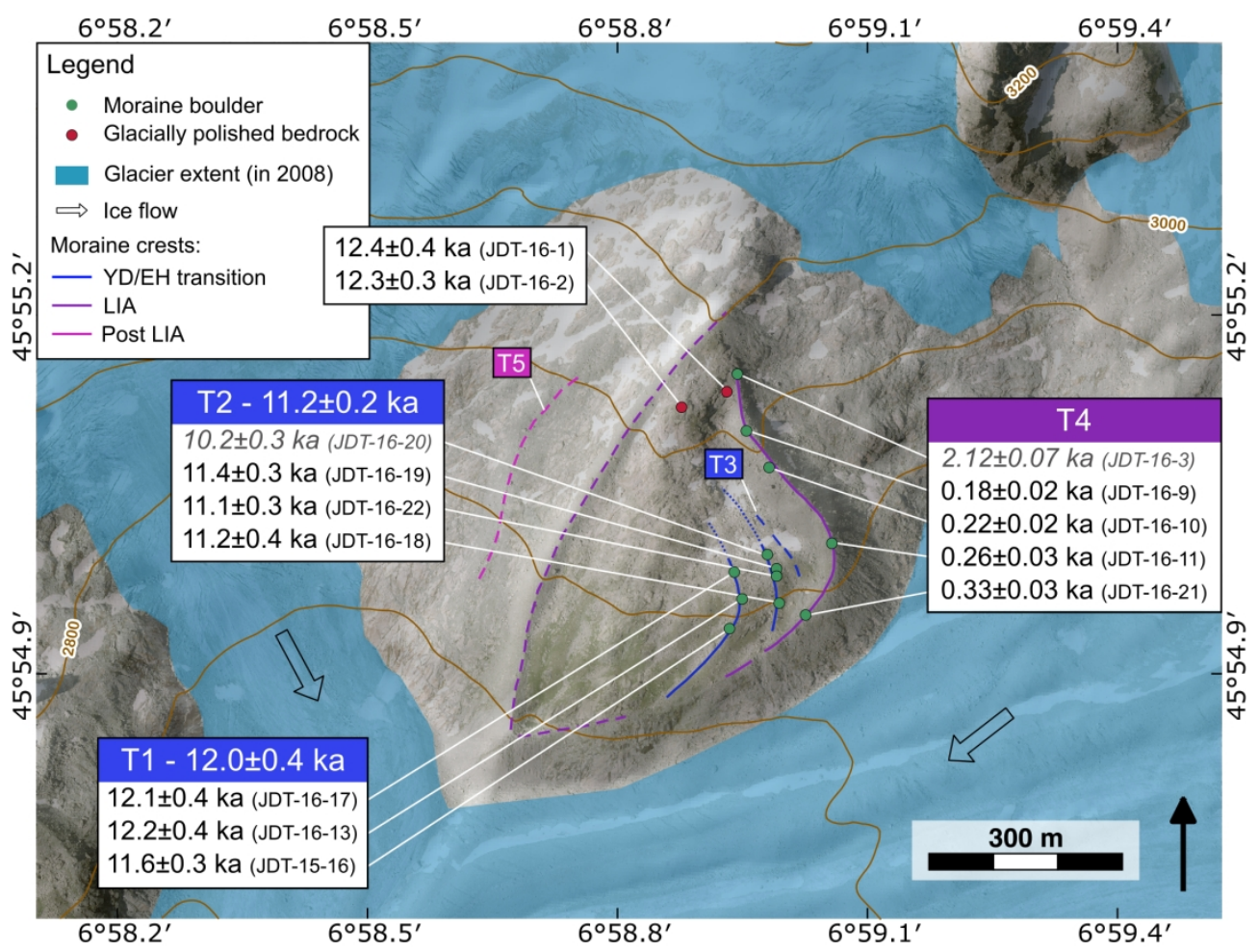



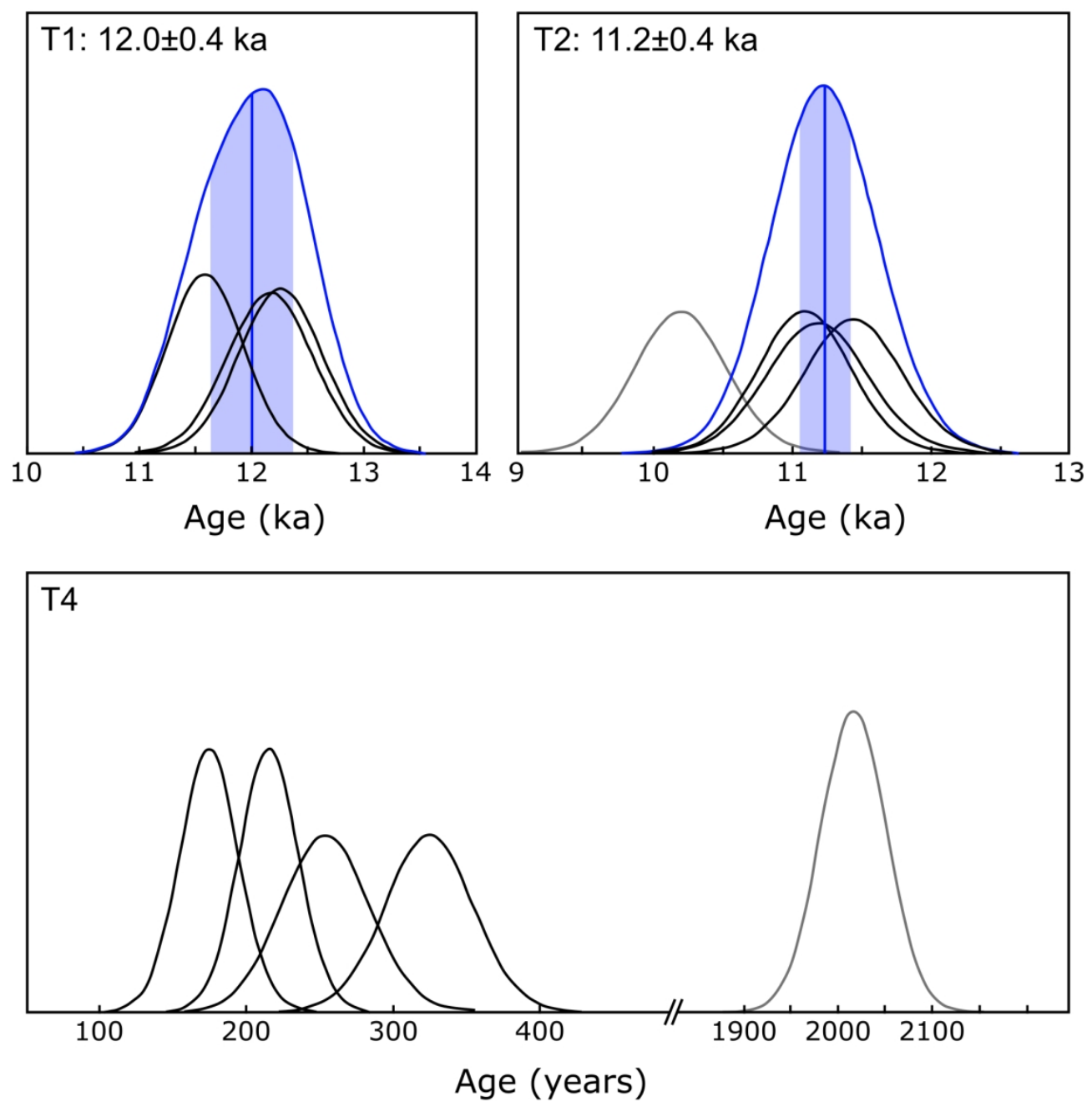

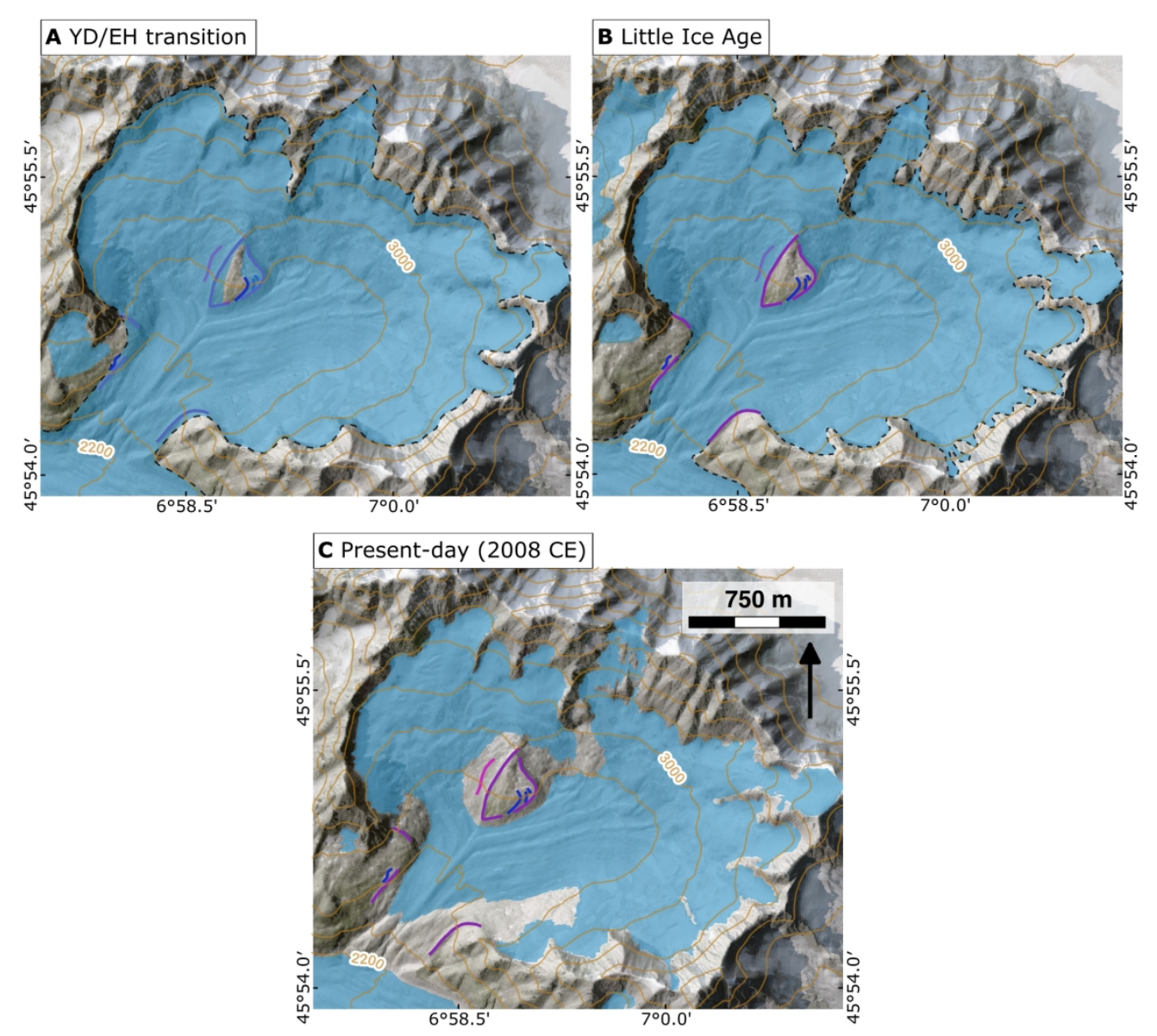

35

36

37

38

39

40

41

42

43

44

45

46

47

48

49

50

51

52

53

54

55

56

57

58

59

60 


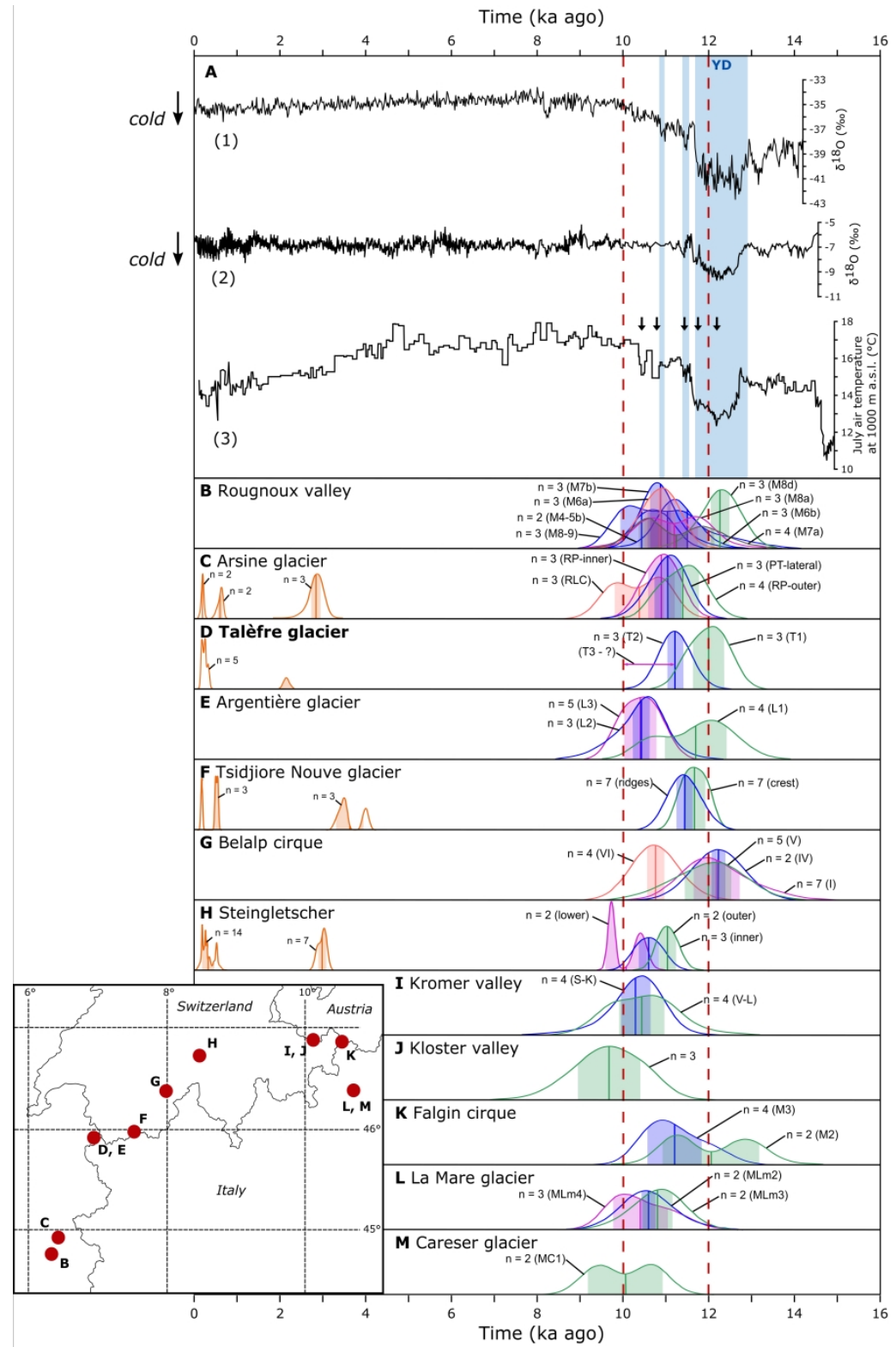




\begin{tabular}{|c|c|c|c|c|c|c|c|c|c|c|c|c|c|c|}
\hline \multirow[b]{2}{*}{ Sample name } & \multirow[b]{2}{*}{$\begin{array}{l}\text { Latitude } \\
\text { (dd) }\end{array}$} & \multirow[b]{2}{*}{$\begin{array}{l}\text { Longitude } \\
\text { (dd) }\end{array}$} & \multirow[b]{2}{*}{$\begin{array}{c}\text { Elevation } \\
\text { (m a.s.1.) }\end{array}$} & \multirow[b]{2}{*}{$\begin{array}{l}\text { Thickness } \\
\text { (mm) }\end{array}$} & \multirow[b]{2}{*}{$\begin{array}{l}\text { Shielding } \\
\text { factor }\end{array}$} & \multirow[b]{2}{*}{$\begin{array}{c}\text { Quartz } \\
\text { weight (g) }\end{array}$} & \multirow[b]{2}{*}{$\begin{array}{l}\text { Carrier } \\
\left(\mathrm{mg}{ }^{9} \mathrm{Be}\right)\end{array}$} & \multirow[b]{2}{*}{$\begin{array}{l}\text { Associated } \\
\text { blank }\end{array}$} & \multirow[b]{2}{*}{${ }^{10} \mathrm{Be} /{ }^{9} \mathrm{Be} \times 10^{-14}$} & \multirow[b]{2}{*}{$\begin{array}{c}\left({ }^{10} \mathrm{Be}\right) \\
\left(x 10^{4} \text { at } \mathrm{g}^{-1}\right)\end{array}$} & \multicolumn{2}{|c|}{ Regional PR } & \multicolumn{2}{|c|}{ Arctic PR } \\
\hline & & & & & & & & & & & $\begin{array}{c}{ }^{10} \mathrm{Be} \text { age } \\
\text { (ka) }\end{array}$ & $\begin{array}{c}1 \sigma \\
\text { uncertainties } \\
(\mathrm{ka})\end{array}$ & $\begin{array}{c}{ }^{10} \mathrm{Be} \text { age } \\
(\mathrm{ka})\end{array}$ & $\begin{array}{c}1 \sigma \\
\text { uncertainties } \\
(\mathrm{ka})\end{array}$ \\
\hline \multicolumn{15}{|l|}{ Moraine samples } \\
\hline $\mathrm{T} 1$ & & & & & & & & & & & \multicolumn{2}{|c|}{$11.97 \pm 0.36(0.46)$} & \multicolumn{2}{|c|}{$12.07 \pm 0.37(0.83)$} \\
\hline JDT-16-17 & 45.91642 & 6.98233 & 2825 & 45 & 0.9063 & 24.67 & 0.3053 & BLC-15Jan 18 & $44.9 \pm 1.4$ & $36.8 \pm 1.2$ & 12.14 & $0.37(0.47)$ & 12.24 & $0.37(0.82)$ \\
\hline JDT-16-13 & 45.91604 & 6.98249 & 2817 & 27 & 0.9635 & 15.35 & 0.3072 & BLC-15Jan 18 & $30.13 \pm 0.93$ & $39.8 \pm 1.2$ & 12.21 & $0.36(0.46)$ & 12.32 & $0.37(0.83)$ \\
\hline JDT-16-16 & 45.91564 & 6.98224 & 2798 & 22 & 0.9635 & 28.65 & 0.3078 & BLC-15Jan 18 & $52.3 \pm 1.6$ & $37.3 \pm 1.2$ & 11.56 & $0.34(0.42)$ & 11.65 & $0.35(0.77)$ \\
\hline $\mathrm{T} 2$ & & & & & & & & & & & \multicolumn{2}{|c|}{$11.21 \pm 0.17(0.32)$} & \multicolumn{2}{|c|}{$11.30 \pm 0.18(0.71)$} \\
\hline JDT-16-20 (O) & 45.91667 & 6.98301 & 2835 & 42 & 0.9638 & 26.58 & 0.3071 & BLC-15Jan 18 & $42.7 \pm 1.4$ & $32.7 \pm 1.1$ & 10.15 & $0.32(0.40)$ & 10.24 & $0.32(0.68)$ \\
\hline JDT-16-19 & 45.91647 & 6.98318 & 2827 & 25 & 0.9638 & 21.49 & 0.3070 & BLC-15Jan 18 & $39.5 \pm 1.3$ & $37.4 \pm 1.2$ & 11.40 & $0.34(0.43)$ & 11.50 & $0.35(0.76)$ \\
\hline JDT-16-22 & 45.91636 & 6.98320 & 2824 & 24 & 0.9638 & 32.44 & 0.3069 & BLC-15Jan 18 & $57.6 \pm 1.8$ & $36.2 \pm 1.1$ & 11.07 & $0.33(0.41)$ & 11.16 & $0.33(0.73)$ \\
\hline JDT-16-18 & 45.91599 & 6.98324 & 2805 & 35 & 0.9527 & 20.18 & 0.3083 & BLC-15Jan 18 & $34.9 \pm 1.2$ & $35.3 \pm 1.2$ & 11.15 & $0.35(0.44)$ & 11.24 & $0.36(0.75)$ \\
\hline \multicolumn{15}{|l|}{$\mathrm{T} 3$} \\
\hline JDT-16-3 (O) & 45.91918 & 6.98241 & 2951 & 20 & 0.9677 & 37.83 & 0.3048 & BLC-08Dec17 & $13.43 \pm 0.42$ & $7.05 \pm 0.23$ & 2.12 & $0.07(0.09)$ & 2.15 & $0.07(0.19)$ \\
\hline JDT-16-10 & 45.91788 & 6.98305 & 2903 & 28 & 0.9625 & 31.26 & 0.3017 & BLC-08Dec17 & $1.56 \pm 0.11$ & $0.78 \pm 0.08$ & 0.22 & $0.02(0.02)$ & 0.22 & $0.03(0.03)$ \\
\hline JDT-16-11 & 45.91683 & 6.98430 & 2842 & 26 & 0.9434 & 36.61 & 0.3063 & BLC-08Dec17 & $1.88 \pm 1.20$ & $0.86 \pm 0.07$ & 0.26 & $0.03(0.03)$ & 0.26 & $0.02(0.03)$ \\
\hline JDT-16-21 & 45.91583 & 6.98377 & 2796 & 22 & 0.9623 & 33.60 & 0.3010 & BLC-08Dec17 & $2.16 \pm 0.12$ & $1.09 \pm 0.08$ & 0.33 & $0.03(0.03)$ & 0.33 & $0.03(0.03)$ \\
\hline \multicolumn{15}{|l|}{ Bedrock samples } \\
\hline JDT-16-1 & 45.91873 & 6.98128 & 2950 & 32 & 0.9667 & 20.09 & 0.3015 & BLC-08Dec17 & $44.2 \pm 1.4$ & $44.0 \pm 1.4$ & 12.43 & $0.38(0.48)$ & 12.54 & $0.39(0.85)$ \\
\hline JDT-16-2 & 45.91894 & 6.98219 & 2943 & 26 & 0.9677 & 17.83 & 0.3048 & BLC-08Dec17 & $38.6 \pm 1.1$ & $43.7 \pm 1.2$ & 12.31 & $0.33(0.44)$ & 12.42 & $0.34(0.81)$ \\
\hline
\end{tabular}

Blanks

Blank name Carrier $\left(\mathrm{mg}{ }^{9} \mathrm{Be}\right) \quad{ }^{10} \mathrm{Be} /{ }^{9} \mathrm{Be} \times 10^{-14} \quad$ Number of ${ }^{10} \mathrm{Be}$ atoms $\left(\mathrm{x} 10^{4} \mathrm{at}\right)$

$\begin{array}{llll}\text { BLC-8Dec17 } & 0.3040 & 0.338 \pm 0.049 & 6.9 \pm 1.0\end{array}$

$\begin{array}{llll}\text { BLC-15Jan18 } & 0.3075 & 0.348 \pm 0.050 & 7.2 \pm 1.0\end{array}$ 

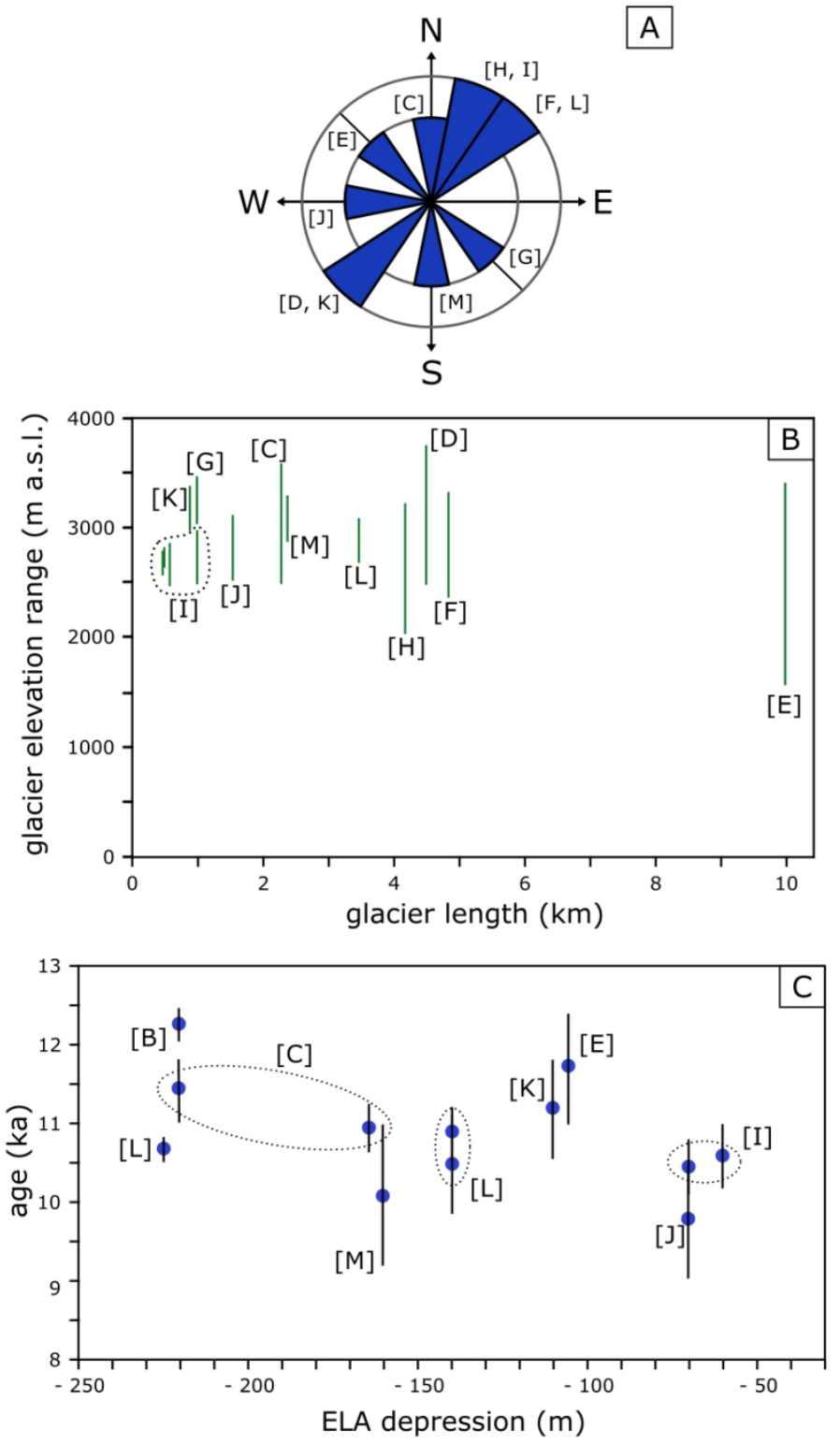
VdR M4-5b

VdR M7a

\begin{tabular}{ccc} 
& \multicolumn{2}{c}{ Regional PR } \\
\cline { 2 - 3 } $\begin{array}{c}\text { Moraine and } \\
\text { sample name }\end{array}$ & $\begin{array}{c}\text { Recalculated } \\
{ }^{10} \text { Be age }(\mathrm{ka})\end{array}$ & $\begin{array}{c}1 \sigma \\
\text { uncertainty } \\
(\mathrm{ka})\end{array}$ \\
\hline Rougnoux Valley (B) (Hofmann 2018)
\end{tabular}

VdR M8d

$\begin{array}{lll}\text { VdR-26 } & 12.43 & 0.42(0.51)\end{array}$

$\begin{array}{lll}\text { VdR-27 } & 12.34 & 0.42(0.50)\end{array}$

$\begin{array}{lll}\text { VdR-28 } & 12.01 & 0.53(0.59)\end{array}$

$\begin{array}{lll}\text { VdR-23 } & 10.38 & 0.42(0.47)\end{array}$

$\begin{array}{lll}\text { VdR-24 } & 12.25 & 0.56(0.62)\end{array}$

$\begin{array}{lll}\text { VdR-25-1 } & 11.76 & 0.40(0.48)\end{array}$

$\begin{array}{lll}\text { VdR-25-2 } & 10.66 & 0.32(0.40)\end{array}$

VdR-10

$11.17 \quad 0.37(0.45)$

VdR-11

VdR-12 (O)

VdR M8a

VdR-16

VdR-17

VdR-18

$11.83 \quad 0.92(0.95)$

$7.41 \quad 0.38(0.41)$

$11.74 \quad 0.38(0.47)$

$10.64 \quad 0.40(0.46)$

$11.21 \quad 1.19(1.21)$

VdR M6b

VdR-7
VdR-8
VdR-9

$11.42 \quad 0.40(0.48)$

$11.17 \quad 0.66(0.70)$

VdR M6a

$10.53 \quad 0.36(0.42)$

VdR-13

$1.38 \quad 0.12(0.13)$

VdR-14

11.12

$0.34(0.42)$

VdR M7b

VdR-15

10.62

$0.38(0.45)$

$10.66 \quad 0.36(0.43)$

$11.13 \quad 0.55(0.60)$

$10.83 \quad 0.33(0.41)$

VdR M8-9

$$
\begin{aligned}
& \text { VdR-4 } \\
& \text { VdR-5 }
\end{aligned}
$$

$10.97 \quad 0.35(0.43)$

VdR-1

$10.35 \quad 0.43(0.49)$

VdR-2

$10.00 \quad 0.36(0.42)$

Arsine Glacier (C) (Schimmelpfennig et al. 2019)

Frontal moraine

Petit Tabuc lateral moraine

Rif de la Planche frontale moraine

Right lateral complex

Piano del Praiet (Federici et al. 2008)

PDP moraine

$\begin{array}{lll}P D P 1 & 15.27 & 0.61(1.32) \\ P D P 2 & 15.00 & 0.83(1.44) \\ \text { PDP3 } & 14.35 & 0.58(1.24) \\ \text { PDP4 } & 13.03 & 0.59(1.18)\end{array}$

Argentière Glacier (E) (Protin et al. 2019)

L1

$\begin{array}{ll}12.21 & 0.58(0.64) \\ 10.10 & 0.65(0.68) \\ 10.63 & 0.42(0.48) \\ 11.88 & 0.68(0.73) \\ 11.93 & 0.55(0.61)\end{array}$

$11.7 \pm 0.7$

$11.4 \pm 0.4$

$11.0 \pm 0.3$

$10.9 \pm 0.3$

$10.4 \pm 0.6$

$14.5 \pm 0.9$

$15.42 \quad 0.61(1.08)$

$15.16 \quad 0.83(1.21)$

$14.52 \quad 0.58(1.02)$

$13.450 .59(0.99)$

$11.1 \pm 0.3$

$11.0 \pm 0.3$

$10.5 \pm 0.6$

$14.6 \pm 0.9$

$12.310 .58(0.94)$

$10.8 \pm 0.7 \quad-105$

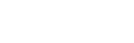

$10.18 \quad 0.65(0.88)$

$10.70 \quad 0.42(0.75)$

$11.97 \quad 0.68(0.99)$

$12.03 \quad 0.55(0.91)$ $\triangle \mathrm{ELA}$ compare (m)

$11.3 \pm 0.9$

$11.6 \pm 0.5$

$11.3 \pm 0.6$

$11.1 \pm 0.5$

$11.0 \pm 0.4$

$11.0 \pm 0.2$

$10.5 \pm 0.5$

$\begin{array}{ll}11.06 & 0.43(0.75)\end{array}$

$12.4 \pm 0.2 \quad-220$

$\begin{array}{ll}12.44 & 0.42(0.86) \\ 12.11 & 0.53(0.90)\end{array}$

$10.45 \quad 0.42(0.74)$

$11.85 \quad 0.40(0.81)$

$11.930 .92(1.16)$

$\begin{array}{ll}11.83 & 0.38(0.80) \\ 10.71 & 0.40(0.74)\end{array}$

$\begin{array}{ll}11.50 & 0.40(0.78) \\ 11.25 & 0.66(0.93)\end{array}$

$\begin{array}{rr}1.39 & 0.12(0.16) \\ 11.21 & 0.34(0.74)\end{array}$

$10.74 \quad 0.36(0.73)$

$11.22 \quad 0.55(0.86)$

$10.5 \pm 0.5$

$\begin{array}{lll}\text { ARG-16-12 } & 11.88 & 0.68(0.73) \\ \text { ARG-16-13 } & 11.93 & 0.55(0.61)\end{array}$ 
L2 L3

$\begin{array}{rrr}\text { ARG-16-1 } & 10.28 & 0.66(0.70) \\ \text { ARG-16-2 } & 10.39 & 0.66(0.70) \\ \text { ARG-15-11 } & 10.65 & 0.32(0.40)\end{array}$

\section{ARG-16-3}

ARG-16-4

ARG-15-12

ARG-16-5 (O)

ARG-16-6

ARG-16-7
$10.4 \pm 0.2$

$10.65 \quad 0.32(0.40)$

$10.61 \quad 0.33(0.41)$

$\begin{array}{ll}10.52 & 0.32(0.40)\end{array}$

$\begin{array}{ll}10.87 & 0.33(0.40)\end{array}$

$17.42 \quad 1.51(1.55)$

$10.04 \quad 0.30(0.38)$

$10.01 \quad 0.34(0.41)$

Romanche Valley (Chenet et al. 2016)

M7

$\begin{array}{rrr}R O-20 & 13.04 & 0.67(0.73) \\ R O-21 & 11.86 & 0.58(0.63) \\ R O-22(O) & 16.15 & 1.86(1.88) \\ R O-23(O) & 7.72 & 0.61(0.64) \\ R O-24(O) & 12.98 & 3.62(3.61) \\ & & \\ R O-15 & 12.29 & 0.93(0.96) \\ R O-16 & 10.30 & 0.89(0.92) \\ R O-17 & 11.72 & 0.63(0.68) \\ R O-18 & 13.10 & 0.69(0.76) \\ R O-19(O) & 2.08 & 0.41(0.41)\end{array}$

Clarée Valley (Cossart et al. 2012)

Stage 2 moraine

$$
\begin{gathered}
C L A \_08 \_13 a \\
C L A \_08 \_13 b \\
C L A+08 \_14
\end{gathered}
$$

Stage 3 moraine

CLA_08_01

CLA_08_02a

CLA_08_02b $(O)$

CLA_08_03

CLA 0804

CLA_08_05

CLA_08_06

CLA_08_10
$11.43 \quad 0.85(0.88)$

$13.21 \quad 0.64(0.71)$

$13.51 \quad 0.93(0.98)$

$\begin{array}{ll}12.15 & 0.42(0.50)\end{array}$

$12.63 \quad 0.74(0.80)$

$14.09 \quad 0.69(0.76)$

$11.78 \quad 0.54(0.59)$

$10.74 \quad 0.61(0.65)$

$\begin{array}{lll}12.51 & 0.81(0.85)\end{array}$

$10.12 \quad 3.19(3.17)$

$9.83 \quad 3.79(3.76)$

$12.5 \pm 0.8$

$\begin{array}{rl}13.16 & 0.67(1.04) \\ 11.93 & 0.58(0.92) \\ 16.27 & 1.86(2.09) \\ 7.79 & 0.61(0.76) \\ 13.09 & 3.62(3.71)\end{array}$

$11.9 \pm 0.8$

$12.38 \quad 0.93(1.19)$

$\begin{array}{ll}10.39 & 0.89(1.08)\end{array}$

$\begin{array}{lll}11.81 & 0.63(0.95)\end{array}$

$13.23 \quad 0.69(1.05)$

$2.1 \quad 0.41(0.43)$

$10.5 \pm 0.2$

$10.47 \quad 0.66(0.90)$

$10.73 \quad 0.32(0.70)$

$10.5 \pm 0.4$

$\begin{array}{ll}10.60 & 0.32(0.70)\end{array}$

$10.96 \quad 0.33(0.72)$

$17.56 \quad 1.51(1.82)$

$\begin{array}{ll}10.11 & 0.31(0.67) \\ 10.10 & 0.34(0.69)\end{array}$

$12.5 \pm 0.9$

$12.0 \pm 0.8$

$12.7 \pm 1.1$

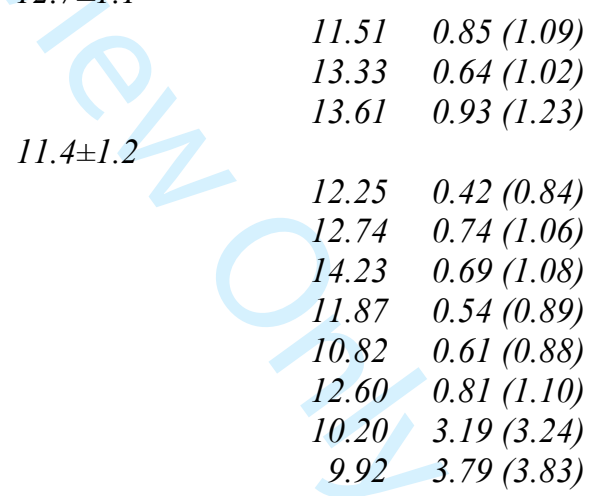

$12.8 \pm 1.1$

$11.5 \pm 1.2$

Tsidjiore Nouve Galcier (F) (Schimmelpfennig et al. 2012)

Crest

$$
\begin{array}{r}
\text { ARO-4 } \\
\text { ARO-1 } \\
\text { ARO-6 } \\
\text { ARO-55 } \\
\text { ARO-5 } \\
\text { ARO-52 } \\
\text { ARO-59 }
\end{array}
$$

ARO-3 (O)

ARO-56 (O)

ARO-2 (O)

Recessional ridges

ARO-21_2010Apr

ARO-21

ARO-22

ARO-21-re

ARO-18
$11.94 \quad 0.18(0.33)$

$\begin{array}{ll}11.90 & 0.21(0.35)\end{array}$

$\begin{array}{ll}11.87 & 0.24(0.36)\end{array}$

$\begin{array}{ll}11.63 & 0.18(0.32)\end{array}$

$\begin{array}{ll}11.58 & 0.21(0.33)\end{array}$

$\begin{array}{ll}11.39 & 0.20(0.33)\end{array}$

$\begin{array}{ll}11.34 & 0.20(0.33)\end{array}$

$\begin{array}{ll}11.20 & 0.19(0.32)\end{array}$

$\begin{array}{ll}11.05 & 0.19(0.32)\end{array}$

$10.96 \quad 0.19(0.31)$

$11.72 \quad 0.28(0.38)$

$11.62 \quad 0.23(0.34)$

$11.48 \quad 0.26(0.37)$

$11.39 \quad 0.20(0.33)$

$11.32 \quad 0.31(0.40)$
$11.7 \pm 0.2$

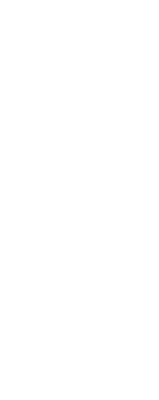

$11.4 \pm 0.2$

$11.8 \pm 0.2$

$12.04 \quad 0.18(0.74)$

$12.01 \quad 0.21(0.75)$

$11.98 \quad 0.24(0.76)$

$11.73 \quad 0.18(0.72)$

$11.67 \quad 0.21(0.72)$

$\begin{array}{ll}11.50 & 0.20(0.70)\end{array}$

$11.44 \quad 0.20(0.70)$

$11.29 \quad 0.19(0.69)$

$11.14 \quad 0.19(0.68)$

$11.05 \quad 0.19(0.67)$

$11.82 \quad 0.28(0.75)$

$11.72 \quad 0.23(0.73)$

$11.58 \quad 0.26(0.73)$

$11.48 \quad 0.20(0.70)$

$11.42 \quad 0.31(0.74)$ 


$\begin{array}{rrr}\text { ARO-8 } & 11.3 & 0.20(0.32) \\ \text { ARO-16 } & 11.2 & 0.19(0.32) \\ \text { ARO-7 (O) } & 12.28 & 0.20(0.35) \\ \text { ARO-15 (O) } & 10.99 & 0.27(0.36)\end{array}$

$\begin{array}{ll}11.41 & 0.20(0.70) \\ 11.29 & 0.19(0.69) \\ 12.39 & 0.20(0.77) \\ 11.08 & 0.27(0.70)\end{array}$

Belalp Cirque (G) (Schindelwig et al. 2012)

Moraine I

$12.0 \pm 0.6$

$12.1 \pm 0.6$

$\begin{array}{lll}\text { VBA-3 (O) } & 15.08 & 0.57(0.66)\end{array}$

$\begin{array}{lll}\text { VBA-22 } & 12.49 & 0.57(0.63)\end{array}$

$\begin{array}{lll}\text { VBA-23 } & 12.57 & 0.82(0.87)\end{array}$

$\begin{array}{lll}\text { VBA-24 } & 11.95 & 0.82(0.86)\end{array}$

$\begin{array}{lll}\text { VBA-25 } & 12.04 & 0.66(0.71)\end{array}$

$\begin{array}{lll}\text { VBA-26 } & 11.09 & 0.71(0.75)\end{array}$

Moraine IV

$$
\text { VBA-6 }
$$

VBA-15 (O)

VBA-16

Moraine $\mathrm{V}$

$12.3 \pm 0.2$

$12.18 \quad 0.61(0.66)$

$\begin{array}{ll}9.82 & 0.94(0.97)\end{array}$

$\begin{array}{rr}12.43 & 0.65(0.70)\end{array}$

VBA-1

VBA-2

$13.36 \quad 0.68(0.74)$

$11.77 \quad 0.57(0.63)$

VBA-4 (O)

VBA-5

VBA-11

$10.32 \quad 0.64(0.68)$

$\begin{array}{ll}11.78 & 0.54(0.60)\end{array}$

$12.16 \quad 0.66(0.72)$

VBA-12

12.78

$0.71(0.77)$

VBA-13

$\begin{array}{ll}11.85 & 0.64(0.70)\end{array}$

Moraine VI

VBA-14

$12.02 \quad 0.61(0.66)$

VBA-17

$10.52 \quad 0.47(0.53)$

VBA-18

$10.53 \quad 0.55(0.60)$

VBA-19

$10.74 \quad 0.51(0.57)$

VBA-20

$10.96 \quad 0.61(0.66)$

Great Aletsch (Schindelwig et al. 2012)

$\begin{array}{rrr}V B A-7 & 13.14 & 0.74(0.80) \\ V B A-8 & 13.36 & 0.54(0.62) \\ V B A-9 & 11.83 & 0.97(1.00) \\ V B A-10 & 12.07 & 0.74(0.79)\end{array}$

$12.6 \pm 0.8$

$\begin{array}{ll}15.17 & 0.57(1.05) \\ 12.58 & 0.57(0.94) \\ 12.65 & 0.82(1.11) \\ 12.02 & 0.82(1.09) \\ 12.11 & 0.66(0.98) \\ 11.16 & 0.71(0.97)\end{array}$

$12.4 \pm 0.2$

$12.25 \quad 0.61(0.96)$

$9.88 \quad 0.94(1.11)$

$12.51 \quad 0.65(0.99)$

$12.2 \pm 0.6$

$13.44 \quad 0.68(1.05)$

$11.86 \quad 0.57(0.90)$

$10.38 \quad 0.64(0.88)$

$\begin{array}{ll}11.85 & 0.54(0.88)\end{array}$

$12.23 \quad 0.66(0.99)$

$12.85 \quad 0.71(1.05)$

$11.92 \quad 0.64(0.95)$

$12.1 \quad 0.61(0.95)$

$10.7 \pm 0.1$

$10.58 \quad 0.47(0.78)$

$10.59 \quad 0.55(0.83)$

$10.81 \quad 0.51(0.82)$

$11.03 \quad 0.61(0.90)$

$10.8 \pm 0.1$

$2.3 \pm 0.6$

$12.3 \pm 0.2$

$12.7 \pm 0.8$

$13.24 \quad 0.74(1.08)$

$13.46 \quad 0.54(0.97)$

$\begin{array}{ll}11.93 & 0.97(1.20)\end{array}$

$12.14 \quad 0.74(1.04)$

GREAT ALETSCH (Kelly et al., 2004)

\begin{tabular}{|c|c|c|}
\hline$A G-1$ & 12.45 & $0.51(0.59)$ \\
\hline$A G$ & 11.69 & $0.81(0.84$ \\
\hline$G-$ & 13.16 & $0.48(0.99$ \\
\hline & 12.09 & 0.7 \\
\hline
\end{tabular}

Steingletscher (H) (Schimmelpfennig et al. 2014)

Outer moraine

$$
\text { STEI-27 }
$$

STEI-11

Inner moraine

$$
\begin{array}{r}
\text { STEI-8 } \\
\text { STEI-9 } \\
\text { STEI-10 }
\end{array}
$$

Lower moraine

$$
\text { STEI-19 }
$$

STEI-20

STEI-21 (O)

$\begin{array}{rl}11.18 & 0.20(0.32) \\ 10.91 & 0.19(0.31) \\ 10.81 & 0.26(0.35) \\ 10.65 & 0.29(0.37) \\ 10.36 & 0.23(0.33) \\ & \\ 10.43 & 0.15(0.28) \\ 9.75 & 0.08(0.24) \\ 8.72 & 0.08(0.22)\end{array}$

$11.0 \pm 0.2$

$10.6 \pm 0.2$

$10.1 \pm 0.5$

$\begin{array}{ll}12.54 & 0.51(0.91) \\ 11.78 & 0.81(1.07) \\ 12.77 & 0.48(0.91) \\ 13.49 & 0.70(1.07)\end{array}$

$12.4 \pm 0.2$

$11.1 \pm 0.2$

$10.7 \pm 0.2$

$10.90 \quad 0.26(0.69)$

$10.73 \quad 0.29(0.69)$

$10.44 \quad 0.23(0.66)$

$10.2 \pm 0.5$

$10.51 \quad 0.15(0.64)$

$\begin{array}{lll}9.82 & 0.08(0.59)\end{array}$

$8.78 \quad 0.08(0.53)$ 
Val Viola (Hormes et al. 2008)

moraine

$12.5 \pm 0.5$

$12.6 \pm 0.5$

$\begin{array}{lll}V V m 4 & 12.14 & 0.65(0.70)\end{array}$

$\begin{array}{lll}V V m 5 & 12.8 & 0.04(0.30)\end{array}$

$12.23 \quad 0.65(0.70)$

$12.92 \quad 0.04(0.78)$

Ferwall Site (Ivy-Ochs et al. 2006)

Schönferwall

$13.4 \pm 0.4$

$13.49 \quad 1.01(1.29)$

$14.12 \quad 0.99(1.31)$

$13.12 \quad 0.65(1.02)$

$13.47 \quad 0.75(1.10)$

Kartell

$\begin{array}{rr}14 & 0.99(1.04) \\ 13.02 & 0.65(0.71) \\ 13.38 & 0.75(0.81)\end{array}$

$12.1 \pm 0.4$

$12.44 \quad 0.96(1.21)$

$11.7 \quad 0.59(0.91)$

$12.42 \quad 1.04(1.28)$

$13.6 \pm 0.4$

$12.2 \pm 0.4$

$\begin{array}{rrr}K 1 & 12.32 & 0.95(1.00) \\ K 2 & 11.58 & 0.59(0.64) \\ K 3 a & 12.3 & 1.04(1.08)\end{array}$

Kromer Valley (I) (Kerschner et al. 2006; Moran et al. 2016b)

Verhulf-Litzer moraine system

$\begin{array}{rrr}\text { KR-1 } & 10.67 & 0.49(0.54) \\ \text { KR-2 } & 11.12 & 0.49(0.56) \\ \text { KR-203 } & 10.68 & 1.27(1.28) \\ \text { KR-303 } & 9.86 & 0.41(0.46) \\ 205(O) & 9.32 & 0.47(0.51) \\ -305(O) & 8.27 & 0.35(0.40)\end{array}$

Scheizer-Kromer moraine system

$\begin{array}{rrr}\text { KR-3 } & 10.58 & 0.50(0.55) \\ \text { KR-4 } & 10.35 & 0.45(0.50) \\ \text { KR-5 } & 10.82 & 0.41(0.48) \\ \text { KR-201 } & 10.02 & 0.92(0.95)\end{array}$

Kloster Valley (J) (Moran et al. 2016b)

Kloster valley moraine system

$\begin{array}{rrr}\text { KL-1 } & 10.51 & 0.51(0.56) \\ \text { KL-2A } & 9.07 & 0.65(0.68) \\ \text { KL-2B } & 9.7 & 0.49(0.54)\end{array}$

Falgin Cirque (H) (Moran et al. 2016a)

M1

$\begin{array}{cccc} & \text { LT-9 } & 12.96 & 0.51(0.59) \\ & & & \\ \text { M3 } & \text { LT-6 } & 11.27 & 0.43(0.49) \\ & \text { LT-7 } & 12.86 & 0.50(0.59) \\ & & & \\ & \text { LT-2 } & 12.01 & 0.46(0.54) \\ & \text { LT-3 } & 11.29 & 0.43(0.50) \\ & \text { LT-4 } & 10.89 & 0.41(0.48) \\ \text { LT-5 } & 10.56 & 0.40(0.47)\end{array}$

La Mare GalcierR (I) (Baroni et al. 2017)

MLm1

$\begin{array}{rrrr} & \text { LAM 13.3 } & 12.21 & 0.41(0.50) \\ & & & \\ \text { MLm3 } & \text { LAM 14.1 } & 10.79 & 0.83(0.86) \\ & \text { LAM 14.2 } & 10.56 & 0.52(0.57) \\ & \text { LAM 13.1 } & 10.63 & 0.63(0.67) \\ & \text { LAM 13.2 } & 11.12 & 0.51(0.56)\end{array}$

$10.6 \pm 0.4$

$10.75 \quad 0.49(0.80)$

$11.20 .50(0.83)$

$10.76 \quad 1.27(1.42)$

$9.94 \quad 0.41(0.71)$

$9.39 \quad 0.47(0.73)$

$8.34 \quad 0.35(0.60)$

$10.4 \pm 0.3$

$10.66 \quad 0.50(0.81)$

$10.43 \quad 0.45(0.76)$

$10.9 \quad 0.41(0.76)$

$10.110 .92(1.10)$
$9.8 \pm 0.7$

$$
10.58
$$$$
9.14 \quad 0.65(0.85)
$$$$
9.78 \quad 0.49(0.76)
$$

$9.8 \pm 0.7$

$-70$

$13.0 \pm 0.5$

$12.1 \pm 1.1$

$11.2 \pm 0.5$

$13.1 \pm 0.5$

$13.08 \quad 0.51(0.94)$

$12.2 \pm 1.1$

$11.37 \quad 0.43(0.79)$

$12.99 \quad 0.50(0.93)$

$11.3 \pm 0.6 \quad-110$

$10.6 \pm 0.4 \quad-60$

$10.5 \pm 0.3 \quad-70$

$12.110 .46(0.86)$

$11.38 \quad 0.43(0.80)$

$10.98 \quad 0.41(0.76)$

$10.64 \quad 0.40(0.74)$

$12.2 \pm 0.4$

$12.3 \pm 0.4$

$-225$

$10.7 \pm 0.2$

$10.9 \pm 0.3$

$\begin{array}{rr}12.32 & 0.41(0.85) \\ 10.87 & 0.83(1.05) \\ 10.64 & 0.52(0.81) \\ 10.72 & 0.63(0.89) \\ 11.2 & 0.51(0.83)\end{array}$

$10.8 \pm 0.2 \quad-225$

$11.0 \pm 0.3 \quad-140$ 
MLm4

$\begin{array}{lrl}\text { LAM 13.4 } & 11.17 & 0.51(0.57) \\ \text { LAM 13.5 } & 10.35 & 0.48(0.54) \\ \text { LAM 13.6 } & 9.92 & 0.40(0.45)\end{array}$

Careser Glacier (J) (Baroni et al. 2017)

$\mathrm{MC} 2$

$\begin{array}{lll}\text { POVE } 3 & 10.08 & 0.42(0.48)\end{array}$

$M C 1$
$10.71 \quad 0.42(0.48)$

$9.420 .43(0.48)$
$10.5 \pm 0.6$

$\begin{array}{rr}11.26 & 0.51(0.84) \\ 10.43 & 0.48(0.78) \\ 10 & 0.40(0.71)\end{array}$

$10.6 \pm 0.6$

$-140$

$10.1 \pm 0.4$

$10.1 \pm 0.9$

POVE 2 